\title{
Crystal Chemistry and Antibacterial Properties of Cupriferous Hydroxyapatite
}

\author{
Arjak Bhattacharjee ${ }^{1}$, Yanan Fang ${ }^{2}$, Thomas J. N. Hooper ${ }^{2}{ }^{-}$, Nicole L. Kelly ${ }^{3}$, Disha Gupta ${ }^{2}$, \\ Kantesh Balani ${ }^{1} \mathbb{1}$, Indranil Manna ${ }^{4}$, Tom Baikie ${ }^{5}$, Peter T. Bishop ${ }^{6}$, Timothy J. White ${ }^{2} \mathbb{D}$ and \\ John V. Hanna ${ }^{3, *(D)}$ \\ 1 Department of Materials Science and Engineering, Indian Institute of Technology, Kanpur 208016, India; \\ amarchalarpath@gmail.com (A.B.); kbalani@iitk.ac.in (K.B.) \\ 2 School of Materials Science and Engineering, Nanyang Technological University, Nanyang Avenue, \\ Singapore 639798, Singapore; YNFang@ntu.edu.sg (Y.F.); thooper@ntu.edu.sg (T.J.N.H.); \\ DISHA001@e.ntu.edu.sg (D.G.); tjwhite@ntu.edu.sg (T.J.W.) \\ 3 Department of Physics, University of Warwick, Coventry CV4 7AL, UK; N.Kelly.1@warwick.ac.uk \\ 4 Department of Metallurgical and Materials Engineering, Indian Institute of Technology, \\ Kharagpur 721302, India; imanna@metal.iitkgp.ernet.in \\ 5 Energy Research Institute @ NTU (ERI@N), Research Technoplaza, Nanyang Technological University, \\ Nanyang Drive, Singapore 637553, Singapore; TBaikie@ntu.edu.sg \\ 6 Johnson Matthey Technology Centre, Blounts Court Rd., Sonning Common, Reading RG4 9NH, UK; \\ peter.bishop@matthey.com \\ * Correspondence: j.v.hanna@warwick.ac.uk; Tel.: +44-7824-541149
}

Received: 6 May 2019; Accepted: 31 May 2019; Published: 4 June 2019

Abstract: Copper-doped hydroxyapatite (HA) of nominal composition $\mathrm{Ca}_{10}\left(\mathrm{PO}_{4}\right)_{6}\left[\mathrm{Cu}_{x}(\mathrm{OH})_{2-2 x} \mathrm{O}_{\mathrm{x}}\right]$ $(0.0 \leq \mathrm{x} \leq 0.8)$ was prepared by solid-state and wet chemical processing to explore the impact of the synthesis route and mode of crystal chemical incorporation of copper on the antibacterial efficacy against Escherichia coli (E. coli) and Staphylococcus aureus (S. aureus) strains. Apatites prepared by solid-state reaction showed unit cell volume dilation from $527.17 \AA^{3}$ for copper-free HA to $533.31 \AA^{3}$ for material of the putative composition $\mathrm{Ca}_{10}\left(\mathrm{PO}_{4}\right)_{6}\left[\mathrm{Cu}_{0.8}(\mathrm{OH})_{0.4} \mathrm{O}_{0.8}\right]$ consistent with $\mathrm{Cu}^{+}$insertion into the [001] hydroxyapatite channel. This was less pronounced (528.30 $\AA^{3}$ to $529.3 \AA^{3}$ ) in the corresponding wet chemical synthesised products, suggesting less complete $\mathrm{Cu}$ tunnel incorporation and partial tenancy of $\mathrm{Cu}$ in place of calcium. X-ray absorption spectroscopy suggests fast quenching is necessary to prevent oxidation of $\mathrm{Cu}^{+}$to $\mathrm{Cu}^{2+}$. Raman spectroscopy revealed an absorption band at $630 \mathrm{~cm}^{-1}$ characteristic of symmetric $\mathrm{O}-\mathrm{Cu}^{+}-\mathrm{O}$ units tenanted in the apatite channel while solid-state ${ }^{31} \mathrm{P}$ magic-angle-spinning nuclear magnetic resonance (MAS NMR) supported a vacancy-Cu $\mathrm{Cu}^{+}$substitution model within the apatite channel. The copper doping strategy increases antibacterial efficiency by $25 \%$ to $55 \%$ compared to undoped HA, with the finer particle sizes and greater specific surface areas of the wet chemical material demonstrating superior efficacy.

Keywords: hydroxyapatite; copper doping; copper oxidation state; heat treatment; antibacterial efficacy; materials characterisation

\section{Introduction}

The crystallochemical formula of apatite is $\left[\mathrm{A}_{4}^{\mathrm{I}} \mathrm{A}_{6}{ }_{6}\right]\left(\mathrm{MO}_{4}\right)_{6}\left[\mathrm{X}_{2}\right]$, where $\mathrm{A}$ is a larger cation (especially alkali, alkaline-earth, lanthanide), $\mathrm{M}$ a smaller cation, and $\mathrm{X}$ an anion [1-3]. These structural elements are arranged as an $\left[\mathrm{A}_{4}^{\mathrm{I}}\right]\left(\mathrm{MO}_{4}\right)_{6}$ framework surrounding an $\left[\mathrm{A}_{6}^{\mathrm{II}}\right]\left[\mathrm{X}_{2}\right]$ channel (Figure 1$)$. Apatites can serve as pigments, catalysts, energy materials, bioceramics and solids for the remediation of hazardous waste with the flexibility to accept a multitude of cation and anion substitutions, thus 
modifying its physical, chemical and biological properties [4-9]. For the tenancy of first-row transition metals including $\mathrm{Cu}, \mathrm{Zn}$, and $\mathrm{Fe}$, size (ionic radius) and oxidation state are the primary determinants of the mode of incorporation, with the heat treatment regime during synthesis also potentially modifying the site substitution profile $[4,10-13]$.
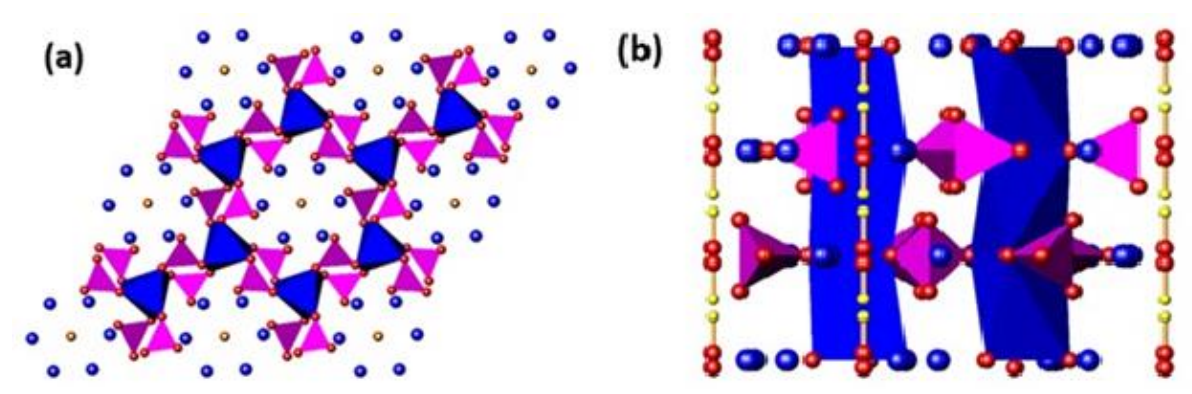

Figure 1. A polyhedral representation of the $\mathrm{HA}\left(\mathrm{Ca}_{10}\left(\mathrm{PO}_{4}\right)_{6}(\mathrm{OH})_{2}\right)$ structure projected along the (a) [001], and (b) [100] directions. The [001] projection highlights the PO4 tetrahedra (purple) corner-shared to CaIO6 metaprisms (blue). The channel $\mathrm{OH}-$ units are surrounded by CaII cations (blue spheres). The [100] projection emphasizes the linear disposition of $\mathrm{OH}^{-}$units in the apatite channel (red and yellow spheres).

Calcium hydroxyapatite (HA, ideal nominal stoichiometry $\left.\mathrm{Ca}_{10}\left(\mathrm{PO}_{4}\right)_{6}(\mathrm{OH})_{2}\right)$ is conventionally assigned hexagonal $P 6_{3} / \mathrm{m}$ symmetry with a $\mathrm{Ca} / \mathrm{P}$ ratio of 1.67 , similar to human bones and teeth, rendering it suitable for orthopaedic, dental and maxillofacial repairs [14,15]. According to Hoover et al. [16] and Weinstein et al. [17], musculoskeletal diseases and assaults are the second most prevalent cause of disability, affecting over 1.7 billion people worldwide. Therefore, HA-based composites are candidates for surgical bone implants. However, post-surgery periprosthetic infections arising from biofilm growth on implant surfaces remain a significant risk addressed by local antibiotic treatment. However, the well-regulated spatial and temporal delivery of drugs to prosthetic infections is challenging [18-20]. One solution is to use prostheses with inherent antibacterial properties. The healing capacity of $\mathrm{Cu}$ has been known from antiquity as described in ancient Indian, Egyptian and European texts [21-23], and more recently, Cu-doped HA has proven an effective treatment against gram-positive and gram-negative bacteria. Shanmugam et al. [24] reported the antibacterial efficiency of HA improved from $25 \%$ to $85 \%$ through the presumed partial displacement of $\mathrm{Ca}$ by $\mathrm{Cu}^{2+}$. Nonetheless, reports of the inclusion of $\mathrm{Cu}^{+}$and/or $\mathrm{Cu}^{2+}$ in $\mathrm{HA}$ are sometimes conjectural, and studies of prosthetic applications usually do not consider crystal chemistry rigorously.

This study describes the incorporation of monovalent copper in HA of a nominal composition of $\mathrm{Ca}_{10}\left(\mathrm{PO}_{4}\right)_{6}\left[\mathrm{Cu}_{\mathrm{x}}(\mathrm{OH})_{2-2 \mathrm{x}} \mathrm{O}_{\mathrm{x}}\right](0 \leq \mathrm{x} \leq 0.8$ at increments of 0.2$)$, where $\mathrm{Cu}^{+}$notionally resides in the apatite channel. The $\mathrm{Cu}$-doped HA systems were prepared by solid-state and wet chemical syntheses to investigate the crystal chemistry and antibacterial efficacy. The effect of the $\mathrm{Cu}$ oxidation state on Escherichia coli (E. coli) and Staphylococcus aureus (S. aureus) mortality and the implications for the deployment of Cu-doped HA as a bio-implant material for musculoskeletal surgery were considered.

\section{Materials and Methods}

\subsection{Synthesis}

Solid-state and wet chemical methods were used to synthesise $\mathrm{Cu}$-doped HA [1,12,25]. In the former, stoichiometric proportions of $\mathrm{CaCO}_{3}$ (ultrapure, Sigma-Aldrich) and $\left(\mathrm{NH}_{4}\right)_{2} \mathrm{HPO}_{4}$ (ultrapure, Sigma Aldrich, Milwaukee, USA) were manually homogenised in an agate mortar for 30 minutes. The mixture was air-sintered $\left(1100^{\circ} \mathrm{C} \mathrm{soak} / 18 \mathrm{~h} / 5^{\circ} \mathrm{C} / \mathrm{min}\right)$ and then air-quenched to produce HA. It has been demonstrated in earlier studies that rapid quenching could fix the $\mathrm{Cu}^{+}$oxidation state without the need to resort to neutral or reducing atmospheres to prevent oxidation to $\mathrm{Cu}^{2+}[4,12,25]$. The grinding, heating and quenching process was repeated until the sample was single phase by powder X-ray 
diffraction (PXRD) (see Figure A1 in Appendix A demonstrating this method). For the cupriferous analogues, copper was introduced as $\mathrm{CuO}$ (ultrapure, Merck, Darmstadt, Germany). As reported herein, the cuprous rather than cupric species was dominant after synthesis and incorporated in HA according to the substitution $2 \mathrm{OH}^{-} \rightarrow \mathrm{Cu}^{+}+\mathrm{O}^{2-}$, while maintaining a $\mathrm{Ca} / \mathrm{P}$ ratio of 1.67 . The putative product compositions were $\mathrm{Ca}_{10}\left(\mathrm{PO}_{4}\right)_{6}\left[\mathrm{Cu}_{\mathrm{x}}(\mathrm{OH})_{2-2 \mathrm{x}} \mathrm{O}_{\mathrm{x}}\right](0.0 \leq \mathrm{x} \leq 0.8)$ (Table 1). These apatites were supplemented by a single composition $\mathrm{Ca}_{10}\left(\mathrm{PO}_{4}\right)_{6}\left[\mathrm{Cu}_{0.6}(\mathrm{OH})_{0.8} \mathrm{O}_{0.6}\right](\mathrm{x}=0.6$, HA6SS1) slowly cooled from $1100{ }^{\circ} \mathrm{C}$ for examination by $\mathrm{X}$-ray absorption spectroscopy (XAS) to study the influence of quenching on the $\mathrm{Cu}$ oxidation state.

Table 1. Sample ID, nominal compositions and lattice parameters of cupriferous hydroxyapatites.

\begin{tabular}{|c|c|c|c|c|c|c|}
\hline Synthesis & Sample ID & Nominal Composition & $\mathrm{x}$ Nominal & $a(\AA)$ & $c(\AA)$ & $\mathrm{V}\left(\AA^{3}\right)$ \\
\hline \multirow{6}{*}{$\begin{array}{l}\text { Solid State } \\
\text { Method }\end{array}$} & HASS $^{a}$ & $\mathrm{Ca}_{10}\left(\mathrm{PO}_{4}\right)_{6}(\mathrm{OH})_{2}$ & 0 & $9.4159(3)$ & $6.8790(3)$ & $527.17(4)$ \\
\hline & $\mathrm{HA}_{2} \mathrm{SS}^{a}$ & $\mathrm{Ca}_{10}\left(\mathrm{PO}_{4}\right)_{6}\left[\mathrm{Cu}_{0.2}(\mathrm{OH})_{1.6} \mathrm{O}_{0.2}\right]$ & 0.2 & $9.4240(4)$ & $6.8887(3)$ & $529.82(5)$ \\
\hline & $\mathrm{HA}_{4} \mathrm{SS}^{a}$ & $\mathrm{Ca}_{10}\left(\mathrm{PO}_{4}\right)_{6}\left[\mathrm{Cu}_{0.4}(\mathrm{OH})_{1.2} \mathrm{O}_{0.4}\right]$ & 0.4 & $9.4309(1)$ & $6.8983(1)$ & $531.34(2)$ \\
\hline & HA6SS $^{a}$ & $\mathrm{Ca}_{10}\left(\mathrm{PO}_{4}\right)_{6}\left[\mathrm{Cu}_{0.6}(\mathrm{OH})_{0.8} \mathrm{O}_{0.6}\right]$ & 0.6 & $9.4353(2)$ & $6.9093(2)$ & $532.70(3)$ \\
\hline & $\mathrm{HA}_{\mathrm{SSS}}{ }^{b}$ & $\mathrm{Ca}_{10}\left(\mathrm{PO}_{4}\right)_{6}\left[\mathrm{Cu}_{0.6}(\mathrm{OH})_{0.8} \mathrm{O}_{0.6}\right]$ & 0.6 & - & - & - \\
\hline & $\mathrm{HA}_{8 S S^{a}}$ & $\mathrm{Ca}_{10}\left(\mathrm{PO}_{4}\right)_{6}\left[\mathrm{Cu}_{0.8}(\mathrm{OH})_{0.4} \mathrm{O}_{0.8}\right]$ & 0.8 & $9.4380(3)$ & $6.9133(2)$ & $533.31(4)$ \\
\hline \multirow{6}{*}{$\begin{array}{c}\text { Wet } \\
\text { Chemical } \\
\text { Method }\end{array}$} & $\mathrm{HAWCM} 700^{\circ} \mathrm{C}^{b}$ & $\mathrm{Ca}_{10}\left(\mathrm{PO}_{4}\right)_{6}(\mathrm{OH})_{2}$ & 0 & $9.4149(6)$ & $6.8776(5)$ & $527.96(8)$ \\
\hline & HAWCM $1100^{\circ} \mathrm{C}^{b}$ & $\mathrm{Ca}_{10}\left(\mathrm{PO}_{4}\right)_{6}(\mathrm{OH})_{2}$ & 0 & $9.4149(6)$ & $6.8776(5)$ & $527.96(8)$ \\
\hline & $\mathrm{HAWCM}^{a}$ & $\mathrm{Ca}_{10}\left(\mathrm{PO}_{4}\right)_{6}(\mathrm{OH})_{2}$ & 0 & $9.4168(3)$ & $6.8792(3)$ & $528.30(5)$ \\
\hline & $\mathrm{HA}_{2} \mathrm{WCM}^{a}$ & $\mathrm{Ca}_{10}\left(\mathrm{PO}_{4}\right)_{6}\left[\mathrm{Cu}_{0.2}(\mathrm{OH})_{1.6} \mathrm{O}_{0.2}\right]$ & 0.2 & $9.4168(3)$ & $6.8817(3)$ & $528.49(4)$ \\
\hline & $\mathrm{HA} \mathrm{WCM}^{a}$ & $\mathrm{Ca}_{10}\left(\mathrm{PO}_{4}\right)_{6}\left[\mathrm{Cu}_{0.6}(\mathrm{OH})_{0.8} \mathrm{O}_{0.6}\right]$ & 0.6 & $9.4199(3)$ & $6.8845(3)$ & $529.05(4)$ \\
\hline & $\mathrm{HA} 8 \mathrm{WCM}^{a}$ & $\mathrm{Ca}_{10}\left(\mathrm{PO}_{4}\right)_{6}\left[\mathrm{Cu}_{0.8}(\mathrm{OH})_{0.4} \mathrm{O}_{0.8}\right]$ & 0.8 & $9.4191(3)$ & $6.8892(3)$ & $529.32(5)$ \\
\hline
\end{tabular}

For soft chemical syntheses, $100 \mathrm{~mL}$ of $0.5 \mathrm{M} \mathrm{Ca}\left(\mathrm{NO}_{3}\right)_{2} \cdot 4 \mathrm{H}_{2} \mathrm{O}$ (ultrapure, Merck, Darmstadt, Germany) was mixed dropwise with $100 \mathrm{~mL}$ of $0.3 \mathrm{M}\left(\mathrm{NH}_{4}\right)_{2} \mathrm{HPO}_{4}$ (ultrapure, Sigma-Aldrich, Milwaukee, USA) at a rate of $2 \mathrm{~mL} / \mathrm{min}$, while maintaining a pH of $10-12$ with $\mathrm{NH}_{4} \mathrm{OH}(25 \%$ $\left.\mathrm{NH}_{3}\right)[26,27]$. The reaction continued for $2 \mathrm{~h}$ at $95-100{ }^{\circ} \mathrm{C}$ under magnetic stirring. The products were collected by centrifugation (6 mins) at ambient temperature $\left(24 \pm 4{ }^{\circ} \mathrm{C}\right)$, washed three times with deionised water and then dried $\left(120^{\circ} \mathrm{C}\right.$ for $\left.24 \mathrm{~h}\right)$. Copper was incorporated as stoichiometric quantities of $\mathrm{Cu}\left(\mathrm{NO}_{3}\right)_{2} \cdot 3 \mathrm{H}_{2} \mathrm{O}$ (ultrapure, Sigma Aldrich, Milwaukee, USA) to the $\mathrm{Ca}\left(\mathrm{NO}_{3}\right)_{2} \cdot 4 \mathrm{H}_{2} \mathrm{O}$ solution and then dried, sintered and quenched as for the solid state route $\left(1100{ }^{\circ} \mathrm{C}\right.$ soak $/ 18 \mathrm{~h} / 5^{\circ} \mathrm{C} / \mathrm{min} /$ air quench). Two additional Cu-free HA samples (HAWCM700 ${ }^{\circ} \mathrm{C}\left(700^{\circ} \mathrm{C} / 18 \mathrm{~h} / 5^{\circ} \mathrm{C} / \mathrm{min}\right)$ and HAWCM $1100^{\circ} \mathrm{C}$ $\left.\left(1100{ }^{\circ} \mathrm{C} / 18 \mathrm{~h} / 5^{\circ} \mathrm{C} / \mathrm{min}\right)\right)$ were prepared as standards for solid-state ${ }^{31} \mathrm{P}$ magic-angle-spinning nuclear magnetic resonance (MAS NMR) by sintering and then slow cooling in the powered-off furnace.

\subsection{Phase Confirmation and Characterisation}

Powder X-ray diffraction (PXRD) patterns were collected using a Bruker D8 Advance instrument (Bruker, Billerica, USA (Bragg-Brentano geometry)) equipped with a Cu K $\alpha(1.5406 \AA$ ) X-ray tube operating at $40 \mathrm{kV}$ and $40 \mathrm{~mA}$ with data accumulated at a step size of $0.02^{\circ} 2 \theta$ and dwell time of $2 \mathrm{~s}$ per step. To determine unit cell parameters, Rietveld analyses were carried out from $20^{\circ}$ to $80^{\circ}$ $2 \theta$ with the TOPAS V3 software (Bruker, Billerica, USA) package [28], assuming a $P 6_{3} / m$ symmetry for $\mathrm{Cu}$-doped HA [1,3]. A pseudo-Voigt peak shape function modelled the Bragg reflections and a four-coefficient Chebychev polynomial, and a $1 / x$ profile background, a zero error, scale factors and lattice dimensions were refined sequentially. The incorporation of $\mathrm{Cu}$ was verified by monitoring the progressive variation of the lattice parameters. Secondary phases, particularly $\mathrm{CuO}, \alpha / \beta$-tricalcium phosphate (TCP, $\left.\mathrm{Ca}_{3}\left(\mathrm{PO}_{4}\right)_{2}\right)$ and $\mathrm{CaO}$ were detected in some samples. The microstructure and microchemistry were analysed by field emission scanning electron microscopy (FESEM, Carl Zeiss SMT AG, Oberkochen, Germany,) and energy dispersive X-ray spectroscopy (EDS) using a Cilas-1064 attachment (Oxford instruments, Abingdon, Oxfordshire, UK). Particle sizing of the resultant undoped and $\mathrm{Cu}$-doped biomaterials was undertaken by laser scattering using ImagJ (2018) software (National Institute of Health \& university of Wisconsin, USA), where 10 different particle sizes are measured 
with a calculated average \pm standard deviation value being reported. Fourier transform infrared spectroscopy (FTIR, Perkin-Elmer Spectrum 2000) (Perkin Elmer, Inc., Waltham, USA) was performed by the $\mathrm{KBr}$ pellet method over a spectral range of 400 to $4000 \mathrm{~cm}^{-1}$ (spectral resolution of $4 \mathrm{~cm}^{-1}$ and accumulated for 32 scans). To confirm O-Cu-O bonding, micro-Raman spectroscopy was performed (Princeton Instruments, STR Raman, TE-PMT detector) in backscattering mode with a Nd YAG green laser $(532 \mathrm{~nm} / 12.5 \mathrm{~mW})$, a $50 X$ objective and a spatial resolution of $0.5 \mathrm{~cm}^{-1}$.

A preliminary assessment of $\mathrm{Cu}$ valence and local coordination was conducted using the $\mathrm{X}$-ray absorption fine structure for catalysis (XAFC) beamline at the Singapore Synchrotron Light Source (SSLS). All X-ray absorption spectra (XAS) were measured at a ring energy of $0.7 \mathrm{GeV}$ and current of $200 \mathrm{~mA}$. A Si (111) crystal monochromator tuned the X-ray energy, and all data were acquired in transmission mode at ambient temperature from pressed powder pellets (10 $\mathrm{mm}$ diameter) from 8850 to $9100 \mathrm{eV}$ bracketing the $\mathrm{Cu} \mathrm{K}$ absorption edge. Comparisons were made against $\mathrm{Cu}_{2} \mathrm{O}$ and $\mathrm{CuO}$ standards. Data were analysed with Athena and Artemis features included in the Demeter software package (V 0.0.25) (National Institute of Standards and Technology, Gaithersburg, USA) with Artemis fittings performed with a k-weight $=1,2,3 ; \mathrm{k}$ range $=3-12.5$ and an $\mathrm{R}$ range $=1-3 \AA$.

Solid-state ${ }^{31} \mathrm{P}$ magic-angle-spinning nuclear magnetic resonance (MAS NMR) data were acquired at $14.1 \mathrm{~T}$ using Bruker Avance II+-600 and Bruker HD-600 spectrometers (Bruker BioSpin, Rheinstetten, Germany) operating at a ${ }^{31} \mathrm{P}$ Larmor frequency of $v_{0}\left({ }^{31} \mathrm{P}\right)=242.96 \mathrm{MHz}$. These measurements were performed using either Bruker $1.9 \mathrm{~mm}$ or $2.5 \mathrm{~mm}$ HXY MAS probes which enabled MAS frequencies $\left(v_{\mathrm{r}}\right)$ of $12-15 \mathrm{kHz}$. All ${ }^{31} \mathrm{P}$ MAS NMR data were externally referenced to the $85 \% \mathrm{H}_{3} \mathrm{PO}_{4}$ (IUPAC standard reference) via a solid ammonium dihydrogen phosphate $\left(\left(\mathrm{NH}_{4}\right) \mathrm{H}_{2} \mathrm{PO}_{4}\right)$ secondary reference which is observed at $\delta_{\text {iso }}=0.99 \mathrm{ppm}$. These data were acquired using a single pulse experiment which utilised high power ${ }^{1} \mathrm{H}$ decoupling during acquisition. A $\pi / 2$ pulse length of $2.6 \mu$ s was calibrated using solid $\left(\mathrm{NH}_{4}\right) \mathrm{H}_{2} \mathrm{PO}_{4}$, and each measurement employed an excitation flip angle of $\pi / 4$ (pulse length of $1.3 \mu \mathrm{s}$ ) and a recycle delay of $180 \mathrm{~s}$. The ${ }^{1} \mathrm{H}$ decoupling field strength during the acquisition was $100 \mathrm{kHz}$. All simulation and deconvolution of the ${ }^{31} \mathrm{P}$ MAS NMR data was undertaken using the DMFit software programme [29].

\subsection{Antibacterial Efficacy}

Gram negative E. coli (MCC2079) bacteria and gram positive S. aureus (MCC2043) bacteria were obtained from the National Centre of Cell Science, Pune, India, cultured in a Luria broth (LB) medium and incubated overnight at $37^{\circ} \mathrm{C}$. A single colony of bacteria was isolated by streaking the culture on an agar plate following $24 \mathrm{~h}$ incubation in fresh medium. Bacterial seeding was performed using this suspension with a bacterial optical density (OD) of 0.1 (at $600 \mathrm{~nm}, 10^{8} \mathrm{CFU} / \mathrm{mL}$ of medium). Apatite powders $\left(1.5 \mathrm{mg}\right.$ ) were mixed with $1 \mathrm{~mL}$ of LB containing $5 \times 10^{8} \mathrm{CFU} / \mathrm{mL}$ bacterial cells of E.coli, which was incubated for $4 \mathrm{~h}$ at $37^{\circ} \mathrm{C}$. A similar method was followed for $S$. aureus, only with the control sample (undoped HA), HA6WCM and HA6SS (composition chosen after analysing the results against $E$. coli). Bacterial assays were performed using 3-(4,5-dimethylthiazol-2-yl)-2,5-diphenyl tetrazolium bromide (MTT) [30], and the optical absorbance of the solution (at $540 \mathrm{~nm}$ ) was measured using a BioTek ELx800 micro-plate reader (Labx, San Diego, USA). Post-exposure, the counts (percentage microorganism reduction, $\mathrm{R} \%$ ) of viable microorganisms on both the solid-state and wet chemical materials were compared with pure HA (positive control sample). The experiments were triple replicated, and an average of the results was taken. The statistical analysis of all data was performed by using a t-test with $95 \%$ confidence level.

\section{Results and Discussion}

\subsection{Phase Assemblages}

The wet chemical route yielded single-phase $\mathrm{Ca}_{10}\left(\mathrm{PO}_{4}\right)_{6}(\mathrm{OH})_{2} \mathrm{HA}$ after slow cooling from $700{ }^{\circ} \mathrm{C}$ but soaking at $1100{ }^{\circ} \mathrm{C}$, and air quenching stabilised $\alpha$-TCP as a secondary phase $(\sim 9.1 \mathrm{wt} \%)$, as 
reported previously (Figure 2b) [27]. For $\mathrm{x}=0.2$ and $\mathrm{x}=0.6$ in $\mathrm{Ca}_{10}\left(\mathrm{PO}_{4}\right)_{6}\left[\mathrm{Cu}_{\mathrm{x}}(\mathrm{OH})_{2-2 \mathrm{x}} \mathrm{O}_{\mathrm{x}}\right]$ apatites, $\mathrm{CaO}$ appears in minor quantity, but for $\mathrm{x}=0.8, \alpha$-TCP (tri-calcium phosphate) and $\beta$-TCP become significant. The solid-state materials developed secondary compounds after the fourth or fifth quench cycle (see Appendix A, Figure A1) as confirmed by quantitative Rietveld analysis (Figure 3a; solid circles). There is also a marked and consistent dilation of lattice parameters with increasing $\mathrm{Cu}$ content (Table 1) in contrast to the observations of Shanmugam and Gopal [24] who studied similar Cu-doped systems (see Figure $3 b$ ). For the present solid-state derived materials, unit cell expansion in the cupriferous analogues is primary evidence that $\mathrm{Cu}$ enters the HA channel $\mathrm{X}$ positions, rather than the Ca crystallographic sites, because direct substitution of $\mathrm{Cu}^{2+}(\mathrm{IR}=0.73 \AA)$ for $\mathrm{Ca}^{2+}(\mathrm{IR}=1.00 \AA)$ would lead to a contraction $[1,10,11]$. The corresponding wet chemical route analogues showed a less evident trend (Figure 3). A typical example is $\mathrm{Ca}_{10}\left(\mathrm{PO}_{4}\right)_{6}\left[\mathrm{Cu}_{0.2}(\mathrm{OH})_{1.6} \mathrm{O}_{0.2}\right]$ (HA2WCM), which contains $\sim 1 \mathrm{wt} \% \mathrm{CaO}$. Rietveld refinement indicated $\mathrm{Cu}$ in the channel $(\mathrm{X})$ site, and a slight excess scattering from the $\mathrm{Ca}$ sites would be consistent with partial $\mathrm{Cu}$ incorporation and the appearance of $\mathrm{CaO}$. However, this interpretation is not quantitative due to the correlation of site chemistry and site occupancy. Since the partitioning of $\mathrm{Cu}$ into the $\mathrm{HA}$ channel $(\mathrm{X})$ and $\mathrm{Ca}\left(\mathrm{A}^{\mathrm{I}}\right)$ positions perturbs the cell parameters in opposing fashions, the simultaneous operation of these mechanisms would lead to marginal overall changes to the unit cell character. Similarly, $\mathrm{Ca}_{10}\left(\mathrm{PO}_{4}\right)_{6}\left[\mathrm{Cu}_{0.6}(\mathrm{OH})_{0.8} \mathrm{O}_{0.6}\right](\mathrm{HA} 6 \mathrm{WCM})$ shows a small volume change compared to the material produced by the solid-state method, and the $\sim 4 \mathrm{wt} \%$ coexistence of $\mathrm{CaO}$ would be consistent with the increased displacement of $\mathrm{Ca}$ by $\mathrm{Cu}$. The Rietveld refinements indicate excess scattering from the A sites that would be consistent with $\mathrm{Cu}$ incorporation.
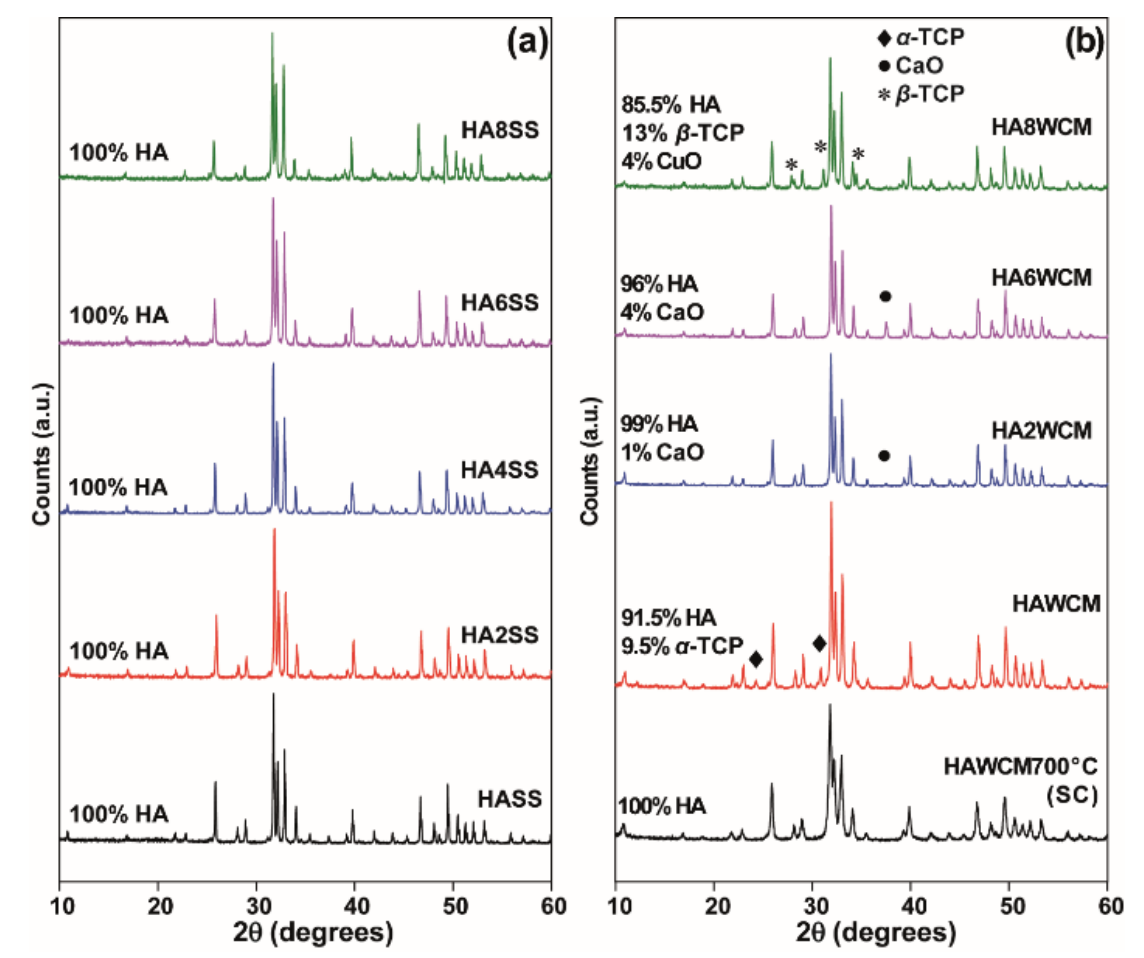

Figure 2. Powder X-ray diffraction (PXRD) data of the undoped and Cu-doped hydroxyapatite (HA) samples prepared by (a) solid-state reaction, and (b) the wet chemical synthetic routes. 

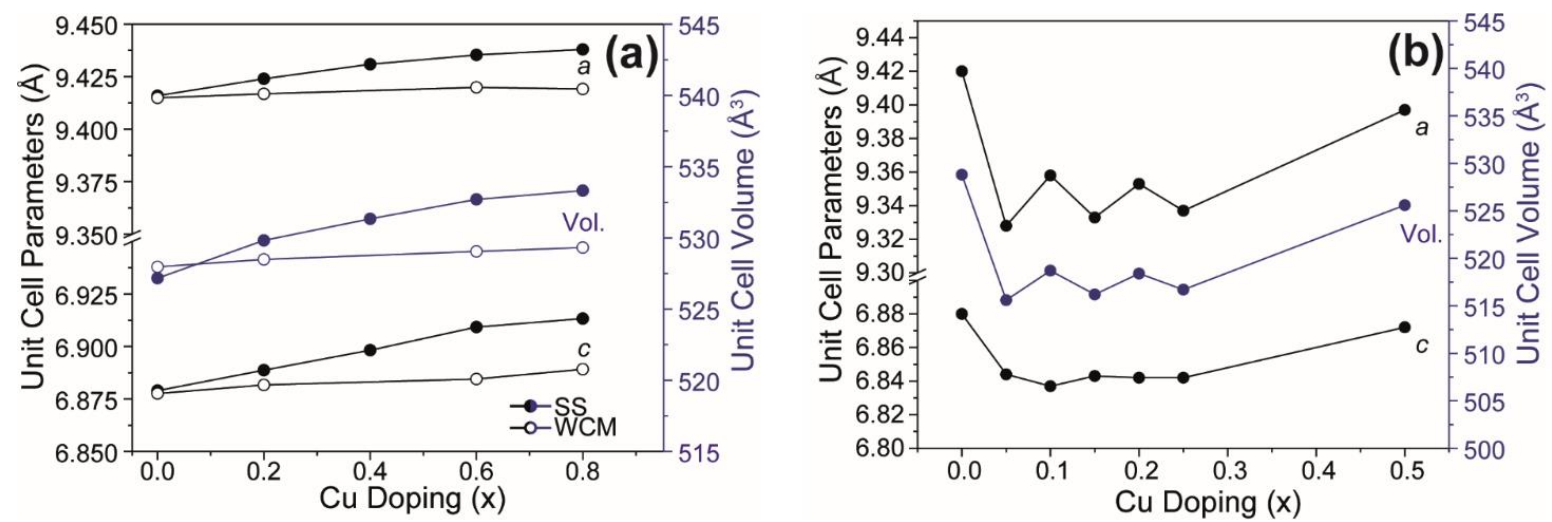

Figure 3. Unit cell and volume parameters (a) as determined from the PXRD for $\mathrm{Ca}_{10}\left(\mathrm{PO}_{4}\right)_{6}\left[\mathrm{Cu}_{\mathrm{x}}(\mathrm{OH})_{2-2 \mathrm{x}} \mathrm{O}_{\mathrm{x}}\right](0 \leq \mathrm{x} \leq 0.8)$ generated by the solid-state and wet chemical synthesis methods in this work, compared with $(\mathbf{b})$ the same parameters from $\mathrm{Cu}$-doped systems generated by Shanmugam et al. [24].

\subsection{Morphology}

The undoped and cupriferous HA existed as agglomerates of varying size and morphology (see Figure 4). Apatites from wet chemistry precursors were irregular but became equant at higher $\mathrm{Cu}$ loadings (see Figure 4a,c,e and Appendix B, Figure A2) and showed more uniform particle sizes compared to the solid-state route (see Figure $4 \mathrm{~b}, \mathrm{~d}, \mathrm{f}$ ) [31-33]. The larger apatite particles produced by solid-state processing could be seen from FESEM and was confirmed by laser scattering. These measurements showed that undoped HA prepared by the wet chemical route was characterised by an average particle size of $249 \pm 66 \mathrm{~nm}$, whereas the equivalent undoped HA prepared by the solid-state route was characterised by an average particle size of $1.09 \pm 0.12 \mathrm{~mm}$ (approximately four times larger). Similarly, laser scattering measurements confirmed that cupriferous apatite particles produced by solid-state processing exhibited a larger average particle size of $1.74 \pm 0.28 \mathrm{~mm}$ in comparison to particle sizes of $323 \pm 42 \mathrm{~nm}$ produced by wet chemical processing (approximately five times larger). Furthermore, larger average particle sizes were exhibited by $\mathrm{Cu}$-doped systems (in comparison to the undoped systems) irrespective of the preparative method. The solid-state materials show no correlation of morphology and $\mathrm{Cu}$ content (see Appendix B, Figure A2). Earlier studies demonstrated that the improved sorption capability of $\mathrm{Cu}$-doped HA is attributable to a higher specific surface area [31,32].

\subsection{Copper Oxidation State}

Fourier transform infrared spectroscopy (FTIR) shows strong bands from $958-1097 \mathrm{~cm}^{-1}$ and $545-600 \mathrm{~cm}^{-1}$, attributable to symmetric and antisymmetric stretching vibrations and bending modes characteristic of the $\mathrm{PO}_{4}{ }^{3-}$ group with $\mathrm{T}_{\mathrm{d}}$ symmetry (Figure $5 \mathrm{a}, \mathrm{d}$ ) [12,33,34]. The band centred at $3573 \mathrm{~cm}^{-1}$ is characteristic of hydroxyl group stretching (Figure $5 \mathrm{a}, \mathrm{c}$ ), while that at $630 \mathrm{~cm}^{-1}$ is ascribed to the $\mathrm{OH}^{-}$libration (Figure 5b,d) [33]. For the solid-state derived apatites, the intensity of the $\mathrm{OH}^{-}$libration band is observed to decrease monotonically with increasing $\mathrm{Cu}$ content and reaches a minimum for the HA8SS sample (see Figure $5 b$ ) consistent with the presumptive displacement of hydroxyl by oxygen in $\mathrm{Ca}_{10}\left(\mathrm{PO}_{4}\right)_{6}\left[\mathrm{Cu}_{x}(\mathrm{OH})_{2-2 x} \mathrm{O}_{x}\right]$. This interpretation aligns with the unit cell volume increase (Table 1) and neutron diffraction confirmation that $\mathrm{Cu}^{+}$replaces $\mathrm{H}^{+}$in the channel [1]. Similarly, for $\mathrm{Ca}_{10}\left(\mathrm{PO}_{4}\right)_{6}\left[\mathrm{Cu}_{0.2}(\mathrm{OH})_{1.6} \mathrm{O}_{0.2}\right](\mathrm{HA} 2 \mathrm{WCM})$ prepared by wet chemistry, the $\mathrm{OH}^{-}$libration band intensity decreases with $\mathrm{Cu}$ doping, but for $\mathrm{Ca}_{10}\left(\mathrm{PO}_{4}\right)_{6}\left[\mathrm{Cu}_{0.6}(\mathrm{OH})_{0.8} \mathrm{O}_{0.6}\right](\mathrm{HA} 6 \mathrm{WCM})$ and $\mathrm{Ca}_{10}\left(\mathrm{PO}_{4}\right)_{6}\left[\mathrm{Cu}_{0.8}(\mathrm{OH})_{0.4} \mathrm{O}_{0.8}\right](\mathrm{HA} 8 \mathrm{WCM})$ it becomes more prominent. A broad band around the $2600-3713 \mathrm{~cm}^{-1}$ region and a weak band at approximately $1629 \mathrm{~cm}^{-1}$ for all samples confirm the presence of adsorbed water. In addition, a weak band around $1430 \mathrm{~cm}^{-1}$ arises from trace amounts of $\mathrm{CO}_{3}{ }^{2-}$, which may result from the reaction of atmospheric $\mathrm{CO}_{2}$ with $\mathrm{Ca}^{2+}$ and $\mathrm{Cu}^{2+}$ species in the surface layer of the apatite powders [33]. 

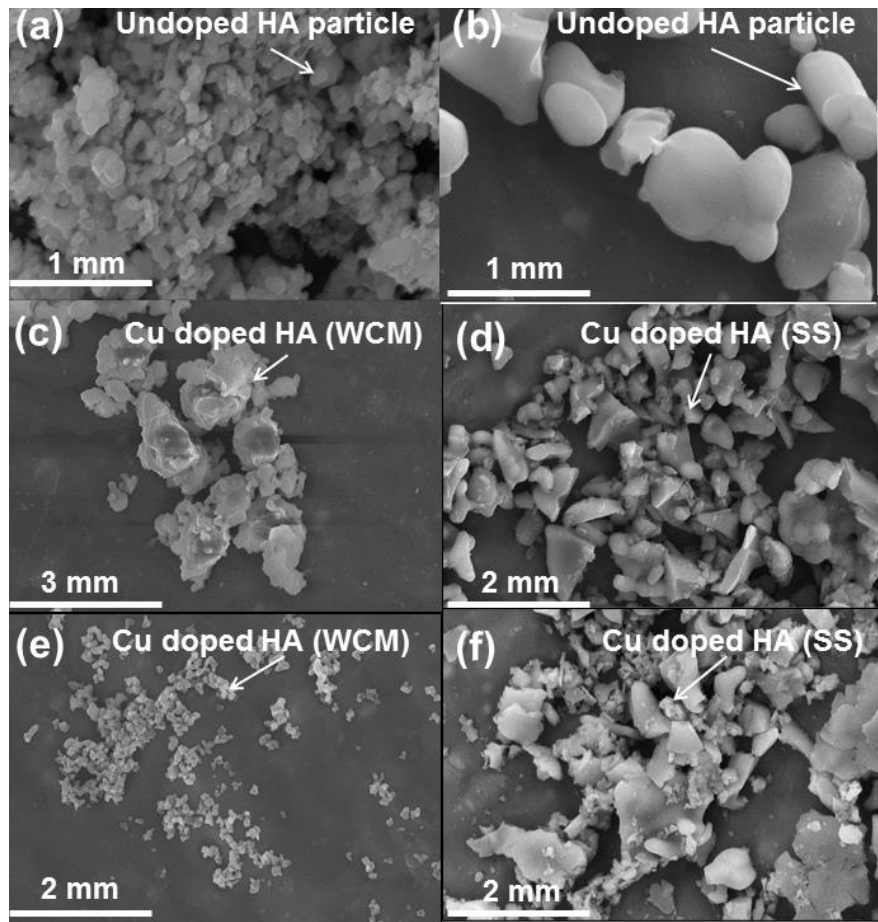

Figure 4. Field emission scanning electron microscopy (FESEM) images of $\mathrm{HA}$ and cupriferous HA systems, including (a) $\mathrm{Ca}_{10}\left(\mathrm{PO}_{4}\right)_{6}(\mathrm{OH})_{2} \mathrm{HAWCM},(\mathbf{b}) \mathrm{Ca}_{10}\left(\mathrm{PO}_{4}\right)_{6}(\mathrm{OH})_{2} \mathrm{HASS},(\mathbf{c}) \mathrm{Ca}_{10}\left(\mathrm{PO}_{4}\right)_{6}\left[\mathrm{Cu}_{0.6}(\mathrm{OH})_{0.8} \mathrm{O}_{0.6}\right]$ HA6WCM, (d) $\mathrm{Ca}_{10}\left(\mathrm{PO}_{4}\right)_{6}\left[\mathrm{Cu}_{0.6}(\mathrm{OH})_{0.8} \mathrm{O}_{0.6}\right] \mathrm{HA} 6 \mathrm{SS},(\mathbf{e}) \mathrm{Ca}_{10}\left(\mathrm{PO}_{4}\right)_{6}\left[\mathrm{Cu}_{0.8}(\mathrm{OH})_{0.4} \mathrm{O}_{0.8}\right] \mathrm{HA} 8 \mathrm{WCM}$ and (f) $\mathrm{Ca}_{10}\left(\mathrm{PO}_{4}\right)_{6}\left[\mathrm{Cu}_{0.8}(\mathrm{OH})_{0.4} \mathrm{O}_{0.8}\right]$ HA8SS.
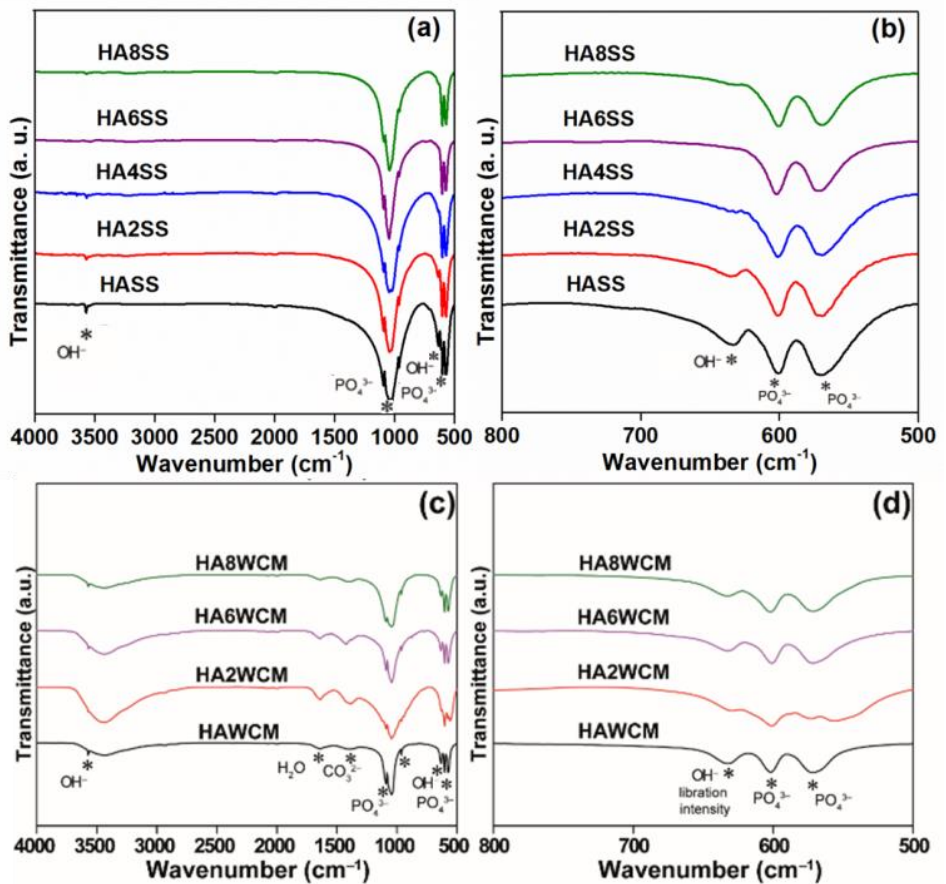

Figure 5. Fourier transform infrared (FTIR) spectra covering the ranges of $4000-500 \mathrm{~cm}^{-1}(\mathbf{a}, \mathbf{c})$ and $800-500 \mathrm{~cm}^{-1}(\mathbf{b}, \mathbf{d})$ for the solid-state synthesised apatites (top) and the wet chemical derived products (bottom).

The Raman spectra invariably show strong resonances from $650-655 \mathrm{~cm}^{-1}$ with two overtones at 1300-1308 $\mathrm{cm}^{-1}$ and 1950-1957 $\mathrm{cm}^{-1}$, respectively (see Figure 6a,b) [2,35,36]. Kazin et al. [35] reported similar bands in $\mathrm{Cu}$-doped strontium hydroxyapatite and ascribed these to the $\mathrm{O}-\mathrm{Cu}^{3+}-\mathrm{O}$ chromophore 
occupying the channel. However, the appearance of $\mathrm{Cu}^{3+}$ is unlikely in the present case [35]. The fully symmetrical stretching vibration $v_{1}{ }^{*}$ of the $\mathrm{PO}_{4}{ }^{3-}$ groups can be assigned to the sharp band in the $961-963 \mathrm{~cm}^{-1}$ range [36], and the weak bands at approximately $1050 \mathrm{~cm}^{-1}$ are due to $v_{3}$ antisymmetric stretching vibrations bands [37].
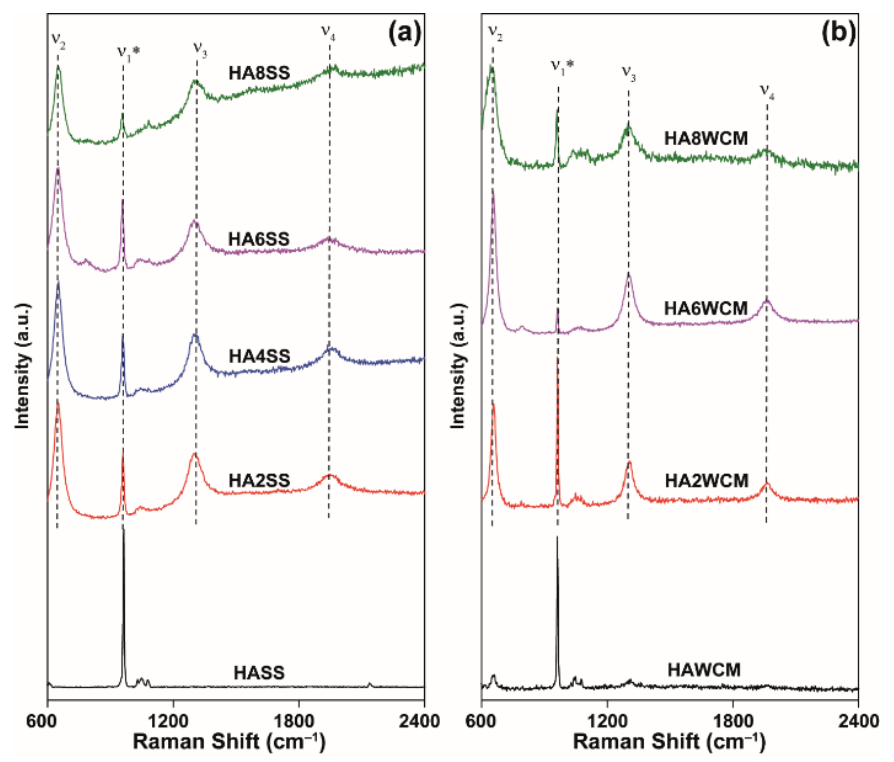

Figure 6. Raman spectra for cupriferous HA systems prepared by the (a) solid-state and (b) wet chemical synthesis routes.

X-ray absorption spectroscopy (XAS) data of solid-state HA6SS and wet chemical HA6WCM samples (both air quenched from $1100^{\circ} \mathrm{C}$ ) were compared with $\mathrm{x}=0.6$ solid-state reacted HA6SS1 (slow cooled from $\left.700{ }^{\circ} \mathrm{C}\right)$ and $\mathrm{CuO}\left(\mathrm{Cu}^{2+}\right)$ and $\mathrm{Cu}_{2} \mathrm{O}\left(\mathrm{Cu}^{+}\right)$primary standards (see the X-ray absorption near edge structure (XANES) data of Figure 7). This study is inconclusive in proving that $\mathrm{Cu}^{2+}$ is present in the slow-cooled HA6SS1 sample, in contrast to Gomes et al. who reported a predominance of the $\mathrm{Cu}^{2+}$ species in cupriferous HA heat treated at $1100{ }^{\circ} \mathrm{C}$ [27]. In addition, the invariance of the measured Cu-O distances at $\sim 1.8-1.9 \AA$ measured from the extended X-ray absorption fine structure (EXAFS) data (see Appendix C, Figure A3) and the subsequent ${ }^{31} \mathrm{P}$ MAS NMR study (see below) could not corroborate the presence of $\mathrm{Cu}^{2+}$ speciation in any of these systems.

\subsection{Local Structure}

The ${ }^{31} \mathrm{P}$ MAS NMR data acquired from the HA and $\mathrm{Cu}$-doped HA systems synthesised by the solid-state and wet chemical methods are presented in Figure 8a,b, respectively. These data exhibit multiple resolved ${ }^{31} \mathrm{P}$ resonances, suggesting that the complex $\mathrm{P}$ speciation in these $\mathrm{Cu}$-doped biomaterials is dominated by at least three chemically distinct environments. All measured ${ }^{31} \mathrm{P}$ chemical shifts and integrated intensities characterising these data are summarised in Table 2 and Figure 9a. The undoped $\mathrm{Ca}_{10}\left(\mathrm{PO}_{4}\right)_{6}(\mathrm{OH})_{2}$ (HASS) underpinning the solid-state synthesis series is dominated by a single narrow resonance at $2.7 \mathrm{ppm}$ which is assigned to a well-formed hexagonal HA phase (see the bottom spectrum in Figure 8a). Upon $\mathrm{Cu}$ incorporation into this HA phase, two significantly broader resonances are now observed at ${ }^{31} \mathrm{P}$ chemical shifts of $\sim 3 \mathrm{ppm}$ and $\sim 2 \mathrm{ppm}$, which are assigned to the orthophosphate units comprising the perturbed hexagonal HA phase. The broader resonance at $\sim 2$ ppm is a consequence of the changing $\mathrm{PO}_{4}$ speciation characterising the $\mathrm{Ca}_{10}\left(\mathrm{PO}_{4}\right)_{6}\left[\mathrm{Cu}_{\mathrm{x}}(\mathrm{OH})_{2-2 x} \mathrm{O}_{\mathrm{x}}\right]$ system which is now influenced by positional disorder caused by the substitution of $\mathrm{Cu}^{+}$metal ions into the [001] HA channel, as corroborated by the PXRD study above. This introduction of $\mathrm{Cu}^{+}$into the [001] channel can introduce different $\mathrm{PO}_{4}$ species with marginally different chemical shifts from the parent material. Figure 3 a shows that the lattice parameters and cell volume observed for the 
$\mathrm{Cu}$-doped HA systems prepared via the solid-state route all exhibit a monotonic increase up to the maximum substitution value of $x=0.8$. The direct quantitation of the $P$ speciation elucidated from this ${ }^{31} \mathrm{P}$ MAS NMR study depicted in Figure 9a exhibits similar monotonic trends describing the decrease of the species represented by the decrease in the $\sim 3.0 \mathrm{ppm}$ resonance and concomitant increase in the species represented by the $\sim 2.0$ ppm resonance. Furthermore, from Figure 9a and Table 2 it can be observed that the ${ }^{31} \mathrm{P}$ resonance linewidths are constantly increasing throughout this substitutional series. These collective indicators suggest that increasing short range positional disorder is associated with progressive $\mathrm{Cu}$ incorporation.

A less intense third resonance is also observed at a chemical shift of $\sim 6.0 \mathrm{ppm}$ which is assigned to distorted $\mathrm{PO}_{4}$ environments proximate to channel vacancies. This ${ }^{31} \mathrm{P}$ chemical shift has been previously identified from thermal decomposition studies of HA systems, and these structural vacancies have also been shown to form readily under more rapid quenching conditions [38,39]. A very small trace of this species is present in the undoped HA sample from the solid-state synthesis suite (see the vertically expanded inset on the HASS data, Figure 8a), and it is postulated that this initial vacancy formation helps to initiate the $\mathrm{Cu}$ incorporation process. It is interesting to note from Figure 9a that, within experimental error, the concentration of this species is largely unchanged throughout this $\mathrm{Cu}$ dopant series. In similar fashion to the XAS and Raman studies reported above, this ${ }^{31} \mathrm{P}$ MAS NMR study cannot detect any paramagnetic influence upon the reported shifts or linewidths that can be associated with the presence of $\mathrm{Cu}^{2+}$ species.

For the analogous ${ }^{31}$ P MAS NMR data measured from wet chemical synthesis series (see Figure $8 \mathrm{~b}$ and Table 2), this suite of samples is underpinned by the well-formed $\mathrm{Ca}_{10}\left(\mathrm{PO}_{4}\right)_{6}(\mathrm{OH})_{2} \mathrm{phases}$ HAWCM $700{ }^{\circ} \mathrm{C}$ and HAWCM $1100{ }^{\circ} \mathrm{C}$ produced from slow-cooled preparations. Like the HASS sample from the air-quenched solid-state syntheses, these samples also exhibit a dominant resonance at $2.7 \mathrm{ppm}$; however, for these latter cases, there is no evidence indicating the formation of channel vacancies as indicated by the ${ }^{31} \mathrm{P}$ resonance at $\sim 6 \mathrm{ppm}$. Furthermore, the slow cooling process adopted for samples HAWCM $700{ }^{\circ} \mathrm{C}$ and HAWCM $1100^{\circ} \mathrm{C}$ has also avoided the onset of $\alpha$-TCP crystallisation. The undoped HA sample produced from the air quenched wet chemical method (HAWCM) does exhibit some resonance intensity at $\sim 6 \mathrm{ppm}$, although the actual contribution from channel vacancies is partially obscured by the manifold of $12^{31} \mathrm{P}$ resonances (observed over the range of $\sim 1-5 \mathrm{ppm}$ ) that characterises the formation of $\alpha$-TCP $[40,41]$. This observation of $\alpha$-TCP formation is corroborated by the PXRD data in Figure $2 b$. Additional broad upfield resonances at $\sim 0$ ppm are also observed in the air-quenched wet chemical sample HA8WCM, and these are assigned to $\beta$-TCP in agreement with the PXRD data in Figure 2b [42,43]. A direct comparison of Figure 8a,b indicates that the wet chemical synthesised suite of samples exhibits a distinct reduction in intensity of the $\sim 6 \mathrm{ppm}$ resonance associated with structural vacancies in comparison to the solid-state synthesised suite. More importantly, the variation in the quantitative analyses of the P species represented by resonances at $\sim 3$ ppm and $\sim 2$ ppm is approximately half of the total variation exhibited by the solid-state prepared samples (see Table 2 and the Figure $9 \mathrm{~b}$ ), and the ${ }^{31}$ P MAS NMR linewidths and linewidth variation is much less pronounced (also approximately half of that exhibited by the solid-state prepared samples). These observations are corroborated by the significantly reduced variation of the lattice parameter and cell volume parameters represented in Figure 3a, and thus infer that the levels of $\mathrm{Cu}$ incorporation into the HA structure via the wet chemical methods are around half that achieved with the solid-state syntheses. 


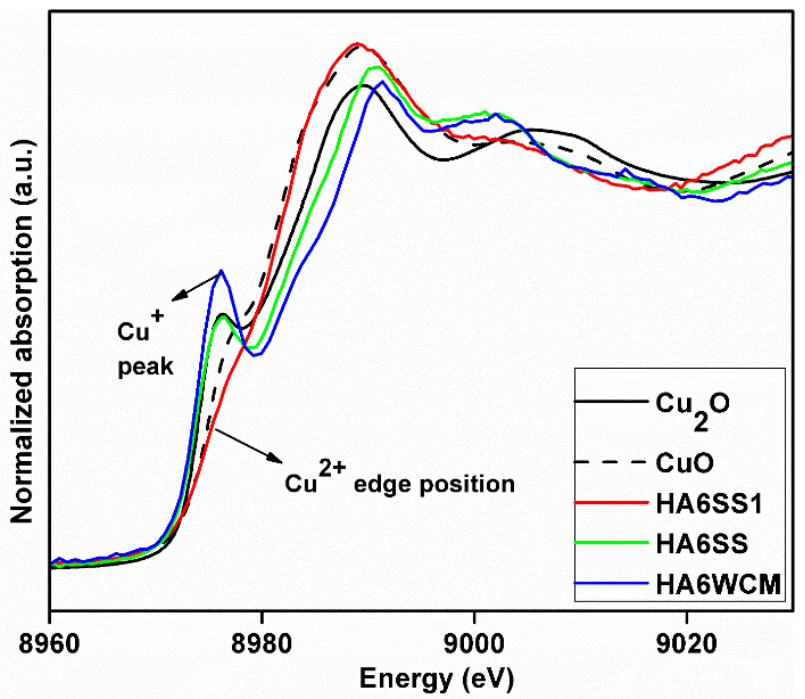

Figure 7. X-ray absorption spectra (XAS) data from $x=0.6$ slow-cooled HA6SS1 sample compared to that derived from the air quenched H6SS and HA6WCM samples and $\mathrm{Cu}_{2} \mathrm{O}$ and $\mathrm{CuO}$ reference materials.

Table 2. ${ }^{31} \mathrm{P}$ MAS NMR chemical shift, linewidth and relative intensity parameters determined from the solid-state and wet chemical synthesised $\mathrm{Cu}$-doped $\mathrm{HA}$ systems $\left(\mathrm{Ca}_{10}\left(\mathrm{PO}_{4}\right)_{6}\left[\mathrm{Cu}_{x}(\mathrm{OH})_{2-2 x} \mathrm{O}_{x}\right]\right.$.

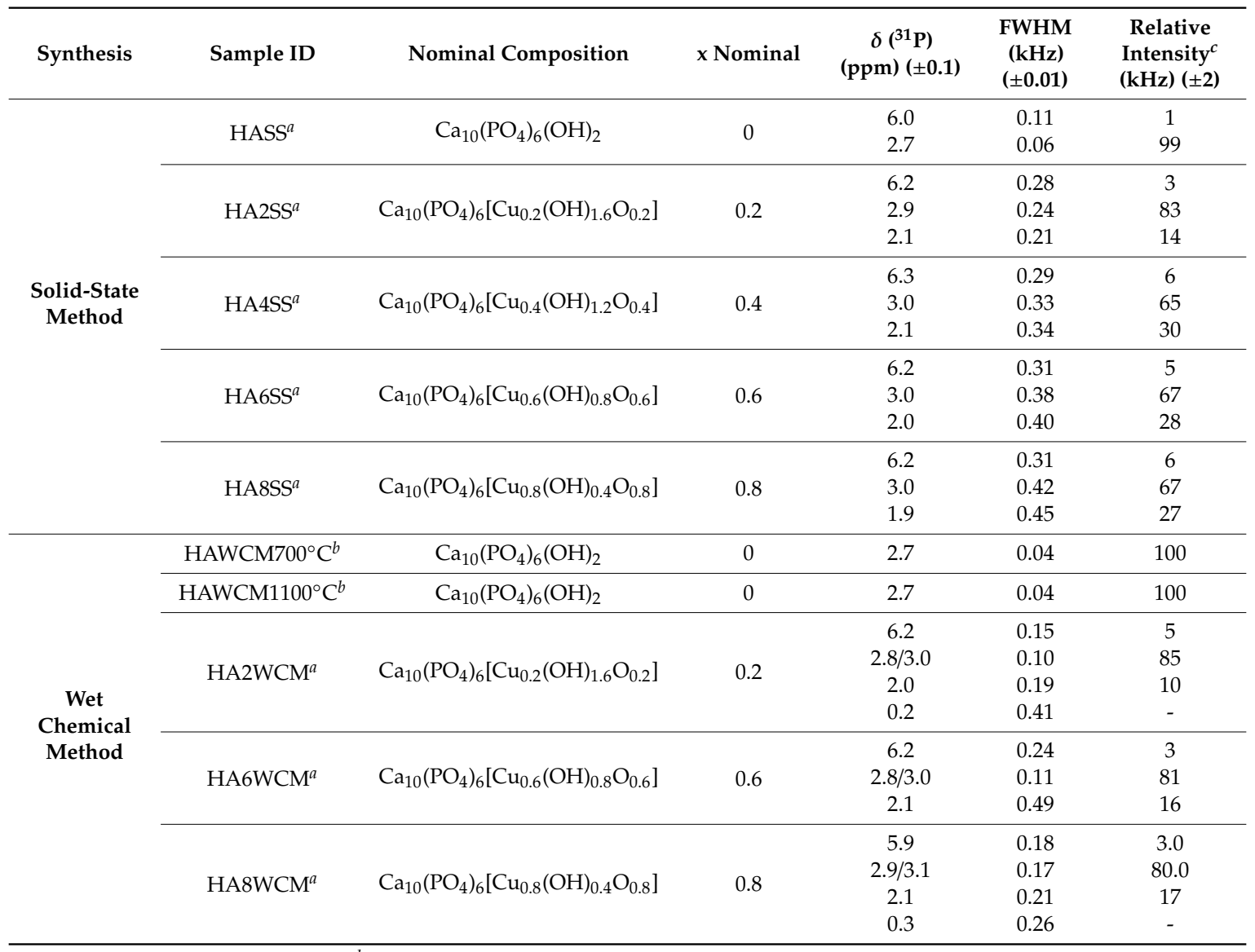

${ }^{a}$ air quenched from $1100^{\circ} \mathrm{C} .{ }^{b}$ slow cooled from $700{ }^{\circ} \mathrm{C} .{ }^{c}$ integrated intensity calculations only include $\mathrm{P}$ species within each $\mathrm{Cu}$-doped HA system (impurity phases not included). 


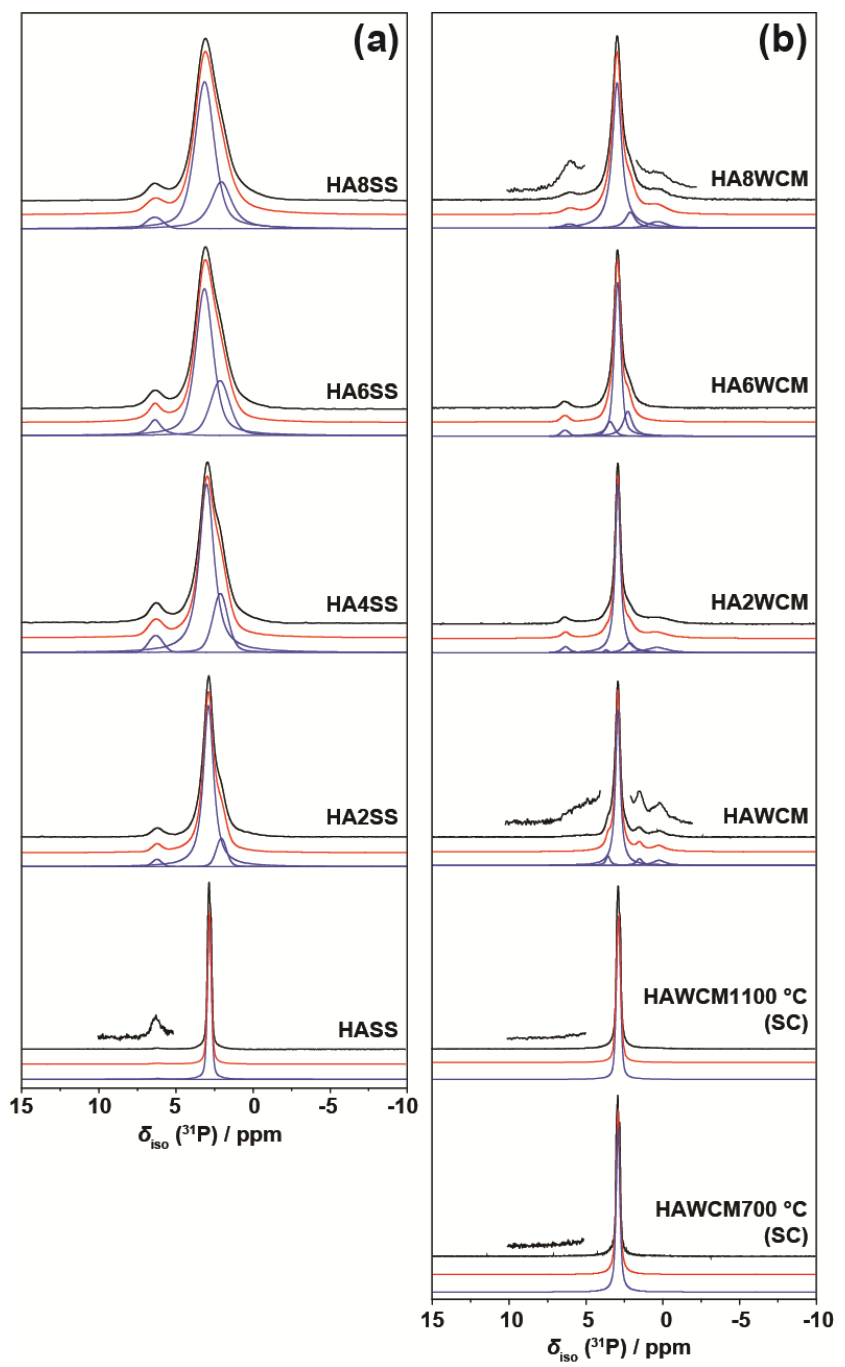

Figure 8. The ${ }^{31} \mathrm{P}$ MAS NMR data $\left(v_{0}\left({ }^{31} \mathrm{P}\right)=242.96 \mathrm{MHz}, v_{\mathrm{r}}=12 \mathrm{kHz}\right)$ showing the experimental spectra (black), total simulated spectra (red), and deconvoluted resonances using Gaussian line shapes (blue) from the suites of $\mathrm{Cu}$-doped HA samples prepared by the (a) solid-state and (b) wet chemical synthetic routes.
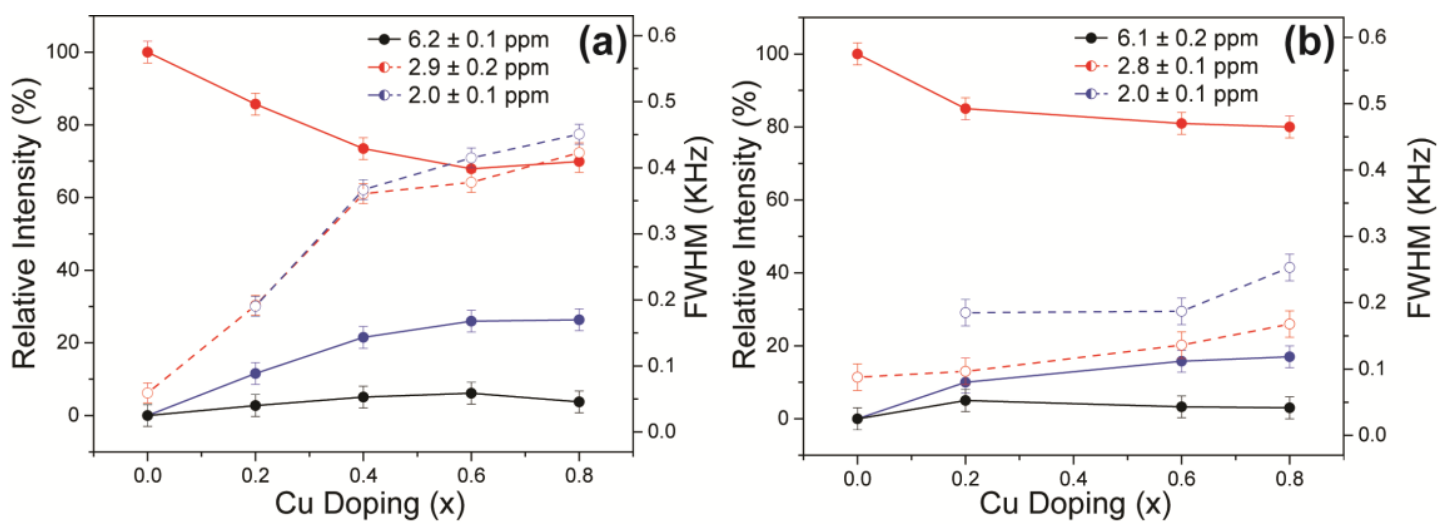

Figure 9. The quantitative estimates of the evolving $\mathrm{P}$ speciation with increasing $\mathrm{Cu}$ doping as determined by ${ }^{31}$ P MAS NMR measurements on the suites of $\mathrm{Cu}$-doped HA samples prepared by the (a) solid-state and (b) wet chemical synthetic routes. 


\subsection{Antimicrobial Efficacy}

All Cu-doped HA were effective against $E$. coli with two tailed $\mathrm{p}$ values less than 0.0001 with significantly enhanced antibacterial efficiency in passing from $35 \%\left(\mathrm{Ca}_{10}\left(\mathrm{PO}_{4}\right)_{6}\left[\mathrm{Cu}_{0.8}(\mathrm{OH})_{0.4} \mathrm{O}_{0.8}\right]\right.$ (HA8SS) to $55 \% \mathrm{Ca}_{10}\left(\mathrm{PO}_{4}\right)_{6}\left[\mathrm{Cu}_{0.6}(\mathrm{OH})_{0.8} \mathrm{O}_{0.6}\right](\mathrm{HA} 6 \mathrm{WCM})$ (Figure 10a). For both preparative techniques, the $\mathrm{x}=0.6$ sample $\mathrm{Ca}_{10}\left(\mathrm{PO}_{4}\right)_{6}\left[\mathrm{Cu}_{0.6}(\mathrm{OH})_{0.8} \mathrm{O}_{0.6}\right]$ showed the best antibacterial efficacy. To test the broader potential of cupriferous HA as an antibacterial agent, HA6WCM and HA6SS (the best performing compositions against E. coli) were tested against $S$. aureus, and showed $25 \%$ and $40 \%$ antibacterial efficiency, respectively (Figure 10b). Shanmugam and Gopal reported that the antibacterial efficacy of $\mathrm{Cu}$-doped $\mathrm{HA}$ varies from $25 \%$ to $85 \%$, where it was assumed that the $\mathrm{Cu}$ substituted at the Ca site, although this was not confirmed [24]. Differences in lattice parameter response with increasing $\mathrm{Cu}$ content in the present study compared to that of Shanmugam and Gopal [24] (see Figure 3a,b) suggest that a direct comparison between these studies is unwarranted. In all instances, the efficacy of the apatites derived by the wet chemical route was superior to solid-state materials with the same copper content. This is expected as the smaller particle size and larger surface area would expose a greater proportion of the bacteria to copper-rich surfaces.

While $\mathrm{Cu}^{+}$is reported as a more effective antibacterial agent compared to $\mathrm{Cu}^{2+}[44,45]$, it is not confirmed that divalent $\mathrm{Cu}$ is present in the materials studied here. For the same nominal composition, wet chemical route $\mathrm{Cu}$-doped apatites have improved antibacterial properties in comparison to the solid-state synthesised samples due to the finer particle size $(\sim 500 \mathrm{~nm})$ and near spherical shape. Finer particle sizes present a greater surface area for the $\mathrm{Cu}$ ions to interact with the bacterial cells. Alternatively, the improved performance of the wet chemical route materials could be due to partial $\mathrm{Cu}$ substitution at the Ca sites, which is reported to give a better antibacterial efficiency, but further work is required. Kim et al. [46] suggested that the use of $\mathrm{Cu}^{+}$nitrate salt as a precursor might not show an antibacterial effect against $E$. coli due to the presence of "nitrate" apatite, although this conclusion is not supported by the present work.
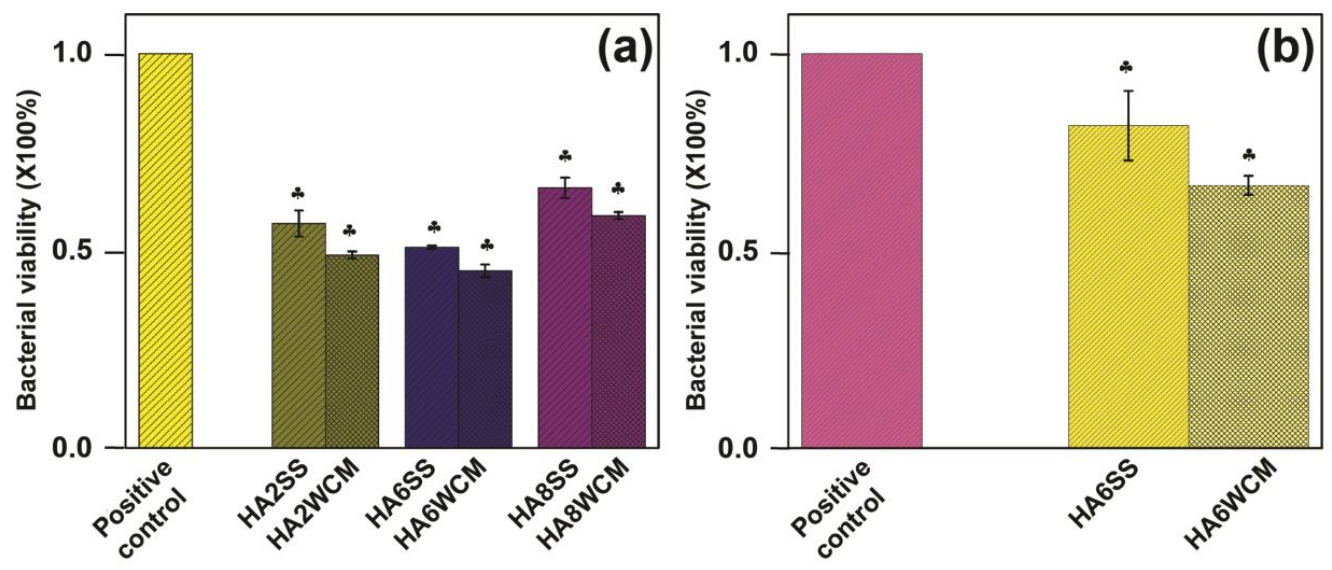

Figure 10. Antibacterial assay of the synthesised Cu-doped HA samples against (a) gram-negative bacteria (E. coli) and (b) gram-positive bacteria (S. aureus).

\section{Conclusions}

Cupriferous HA Ca ${ }_{10}\left(\mathrm{PO}_{4}\right)_{6}\left[\mathrm{Cu}_{\mathrm{x}}(\mathrm{OH})_{2-2 \mathrm{x}} \mathrm{O}_{\mathrm{x}}\right](0.0 \leq \mathrm{x} \leq 0.8)$ was prepared by conventional solid-state reaction and a wet chemical precipitation routes. The PXRD and the ${ }^{31} \mathrm{P}$ MAS NMR studies revealed that the substitution site of $\mathrm{Cu}$ into the HA framework is controlled by (primarily) the synthesis method and heat treatment process, with the solid-state route yielding single phase HA across all $\mathrm{Cu}$ concentrations $(\mathrm{x} \leq 0.6)$. The wet chemical materials were often multiphase but show superior antibacterial activity against $E$. coli and S. aureus ( $20 \%$ improvement) due to the finer particle size and greater surface area for bacterial interaction. In addition, the wet chemical route may allow partial $\mathrm{Cu}$ replacement of $\mathrm{Ca}$, rather than in the apatite channel. This may lead to improved antimicrobial 
efficacy. The XAS, Raman and solid-state NMR studies confirm that $\mathrm{Cu}^{+}$is the dominate oxidation state within these suites of prepared samples, with no definitive evidence for the presence of $\mathrm{Cu}^{2+}$ able to be measured. Previous antibacterial characterisation studies have shown that $\mathrm{Cu}+$ is more toxic to bacteria as compared to $\mathrm{Cu}^{2+}[44,45]$. Antibacterial efficacy of $\mathrm{Cu}$ sited in the HA channel $(\mathrm{X})$ position is a new finding, and the effect of mixed $\mathrm{Cu}$ oxidation states is worthy of further investigation. Future work could be directed to quantifying the efficiency of multi-valent $\mathrm{Cu}$-doped HA against alternative microbe communities.

Author Contributions: Conceptualization, P.T.B., T.J.W. and J.V.H.; methodology, T.B., P.T.B., T.J.W. and J.V.H.; formal analysis, A.B., Y.F., T.J.N.H., N.L.K., D.G., T.B., T.J.W. and J.V.H.; resources, K.B., I.M., P.T.B., T.J.W. and J.V.H.; writing-original draft preparation, A.B., Y.F., T.J.N.H., D.G., T.B., T.J.W. and J.V.H.; writing-review and editing, N.L.K., T.J.W. and J.V.H.; visualization, A.B.,Y.F., T.J.N.H., N.L.K., T.B., T.J.W. and J.V.H.; supervision, K.B., I.M., T.J.W. and J.V.H.; funding acquisition, K.B., I.M., P.B., T.J.W. and J.V.H.

Funding: Johnson Matthey are gratefully acknowledged for the fellowship supporting TB. KB acknowledges the Swarnajayanti Fellowship, DST, Govt. of India (project no. DST/MET/2017476), and IM acknowledges the JC Bose Fellowship and Project 'DGL', DST, New Delhi, for partial support of AB. NLK thanks EPSRC for a PhD studentship through the EPSRC Centre for Doctoral Training in Molecular Analytical Science (EP/L015307/1). JVH thanks the EPSRC, the University of Warwick and the Birmingham Science City Program for partial funding of the solid-state NMR infrastructure at Warwick. The latter program accessed the Birmingham Science City Advanced Materials Project 1: Creating and Characterising Next Generation Advanced Materials, which derived support from Advantage West Midlands (AWM) and the European Regional Development Fund (ERDF).

Acknowledgments: The authors would also like to acknowledge the Singapore Synchrotron Light Source (SSLS) for providing the necessary facility access for conducting the XAS measurements; this Laboratory is a National Research Infrastructure facility under the Singaporean National Research Foundation. The authors would like to thank Du Yonghua and Xi Shibo for assistance in acquiring the XAS data. The authors would like to acknowledge Aditi Pandey, Anshul Gupta and Pradyut Sengupta for their help with the bacteria culture experiment and SEM. H.S.Maiti, Bikramjit Basu and Faizal Siddiqui are also acknowledged for useful insights and suggestions regarding the manuscript preparation.

Conflicts of Interest: The authors declare no conflict of interest.

\section{Appendix A}

As discussed in the main text, the preparation of single-phase Cu-doped HA via the solid-state synthesis route is only achieved after the 4th or 5th quenching cycle, as shown for case of sample HA2SS below. In contrast, a similar result is achieved after one only quench cycle when the wet chemical method is implemented. This is the primary evidence suggesting that the wet chemical approach is more time efficient approach for producing single phase $\mathrm{Cu}$-doped HA systems.

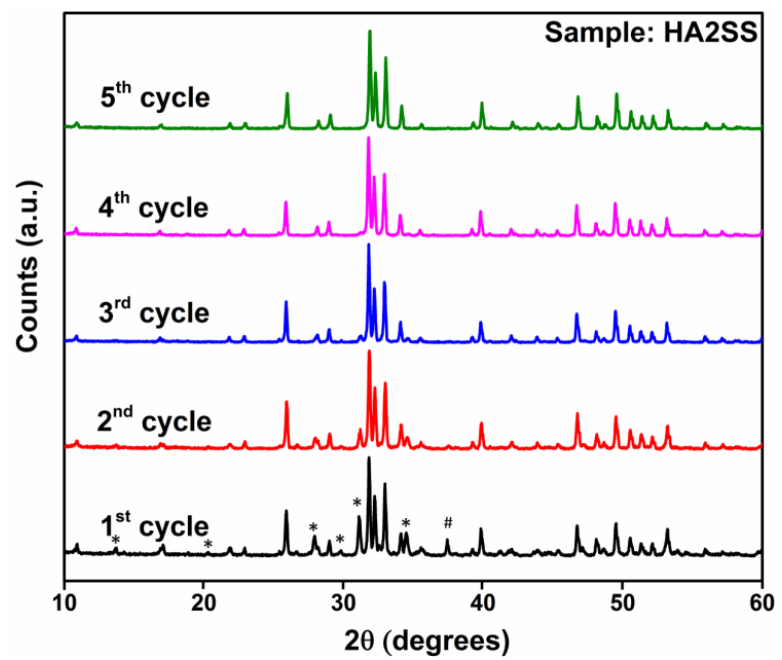

Figure A1. PXRD data showing the phase composition of sample HA2SS after successive sintering/quench cycles. The impurities observed are $\beta$-TCP (identified with *) and CaO (identified with \#). 


\section{Appendix B}

The main text discussion reports that a particle size $<500 \mathrm{~nm}$ is observed from the FESEM images of the samples produced via the wet chemical route. This smaller particle size of wet chemical route samples shows an improved antibacterial efficacy compared to the solid-state prepared samples.

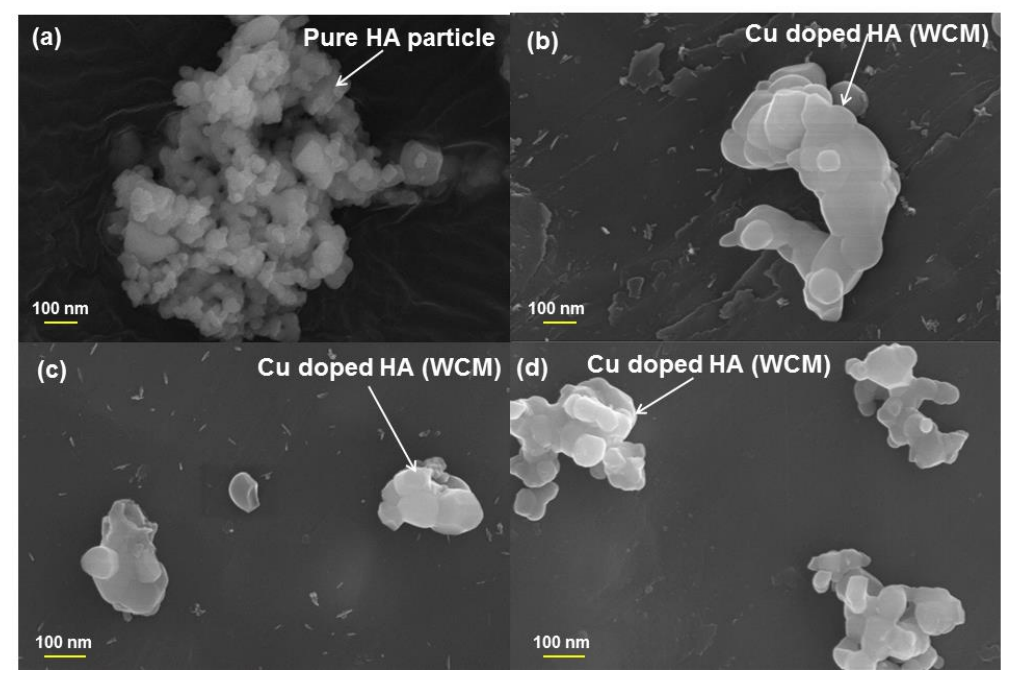

Figure A2. FESEM images of samples (a) HAWCM, (b) HA2WCM, (c) HA6WCM and (d) HA8WCM synthesised via the wet chemical route.

\section{Appendix C}

As pointed out in the main text, the EXAFS data of certain air quenched and slow cooled samples prepared via the solid-state and wet chemical routes are presented below. The first shell EXAFS fittings were used to determine the $\mathrm{Cu}-\mathrm{O}$ distances in the respective samples. These distances all appear invariant within a $\sim 1.8-1.9 \AA$ range, thus suggesting the presence of a constant $\mathrm{Cu}$ oxidation state (i.e., $\mathrm{Cu}^{+}$) throughout.
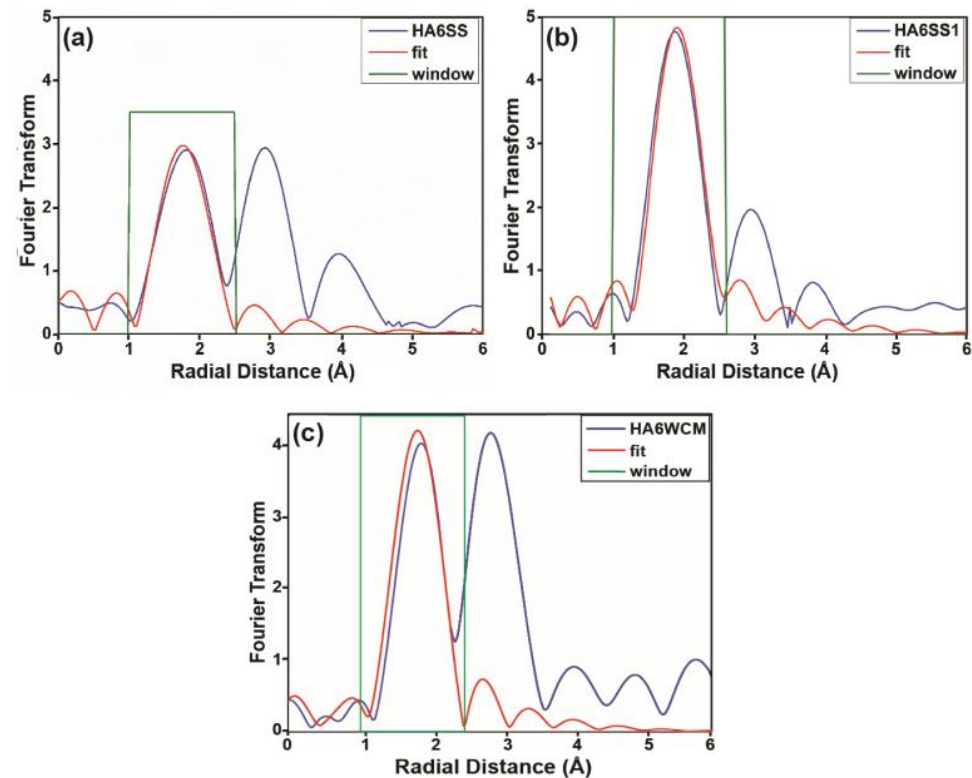

Figure A3. 1st shell EXAFS data from (a) the air-quenched sample HA6SS obtained from the solid-state reaction route, (b) the slow cooled sample HA6SS1 obtained from the solid-state reaction route and (c) the air quenched sample HA6WCM obtained from wet chemical reaction route. 


\section{References}

1. Baikie, T.; Ng, G.M.H.; Madhavi, S.; Pramana, S.S.; Blake, K.; Elcombe, M.; White, T.J. The crystal chemistry of the alkaline-earth apatites $\mathrm{A}_{10}\left(\mathrm{PO}_{4}\right)_{6} \mathrm{Cu}_{\mathrm{x}} \mathrm{O}_{\mathrm{y}}(\mathrm{H})_{\mathrm{z}}(\mathrm{A}=\mathrm{Ca}$, Sr and Ba). Dalton Trans. 2009, 34, 6722-6726. [CrossRef] [PubMed]

2. Kazin, P.E.; Zykin, M.A.; Dinnebier, E.E.; Magdysyuk, O.V.; Tretyakov, Y.D.; Jansen, M. An Unprecedented Process of Peroxide Ion Formation and its Localization in the Crystal Structure of Strontium Peroxy-Hydroxyapatite $\mathrm{Sr}_{10}\left(\mathrm{PO}_{4}\right)_{6}\left(\mathrm{O}_{2}\right)_{x}(\mathrm{OH})_{2-2 x}$. Z. Anorg. Allg. Chem. 2012, 638, 909-919. [CrossRef]

3. White, T.; Ferraris, C.; Kim, J.; Madhavi, S. Apatite-An Adaptive Framework Structure. Rev. Mineral Geochem. 2005, 57, 307-401. [CrossRef]

4. Kazin, P.E.; Karpov, A.S.; Jansen, M.; Nuss, J.; Tretyakov, Y.D. Crystal structure and properties of strontium phosphate apatite with oxocuprate ions in hexagonal channels. Z. Anorg. Allg. Chem. 2003, 629, 344-352. [CrossRef]

5. Dong, Z.; White, T.J.; Wei, B.; Laursen, K. Model apatite systems for the stabilization of toxic metals: I, calcium lead vanadate. J. Am. Ceram. Soc. 2002, 85, 2515-2522. [CrossRef]

6. Ben Moussa, S.; Lachheb, J.; Gruselle, M.; Maaten, B.; Kriis, K.; Kanger, T.; Tõnsuaadu, K.; Badraoui, B. Calcium, barium and strontium apatites: a new generation of catalysts in the Biginelli reaction. Tetrahedron 2017, 73, 6542-6548. [CrossRef]

7. Othmani, M.; Bachoua, H.; Ghandour, Y.; Aissa, A.; Debbabi, M. Synthesis, characterization and catalytic properties of copper-substituted hydroxyapatite nanocrystals. Mater. Res. Bull. 2018, 97, 560-566. [CrossRef]

8. Marrero-López, D.; Díaz-Carrasco, P.; Peña-Martínez, J.; Ruiz-Morales., J.C.; Ramos-Barrado, J.R. Lanthanum germanate-based apatites as electrolyte for SOFCs. Fuel Cells 2011, 11, 65-74.

9. Shepherd, J.H.; Shepherd, D.V.; Best, S.M. Substituted hydroxyapatites for bone repair. J. Mater. Sci. Mater. Med. 2012, 23, 2335-2347. [CrossRef]

10. Shannon, R.D. Revised effective ionic radii and systematic studies of interatomic distances in halides and chalcogenides. Acta Cryst. 1976, A32, 751-767. [CrossRef]

11. Renaudin, G.; Gomes, S.; Nedelec, J.M. First-row transition metal doping in calcium phosphate bioceramics: a detailed crystallographic study. Materials 2017, 10, 92. [CrossRef] [PubMed]

12. Karpov, A.S.; Nuss, J.; Jansen, M.; Kazin, P.E.; Tretyakov, Y.D. Synthesis, crystal structure and properties of calcium and barium hydroxyapatites containing copper ions in hexagonal channels. Solid State Sci. 2003, 5, 1277-1283. [CrossRef]

13. Mercier, P.H.J.; Le Page, Y.; Whitfield, P.S.; Mitchell, L.D.; Davidson, I.J.; White, T.J. Geometrical parameterization of the crystal chemistry of $\mathrm{P}_{3} / \mathrm{m}$ apatites: comparison with experimental data and ab initio results. Acta Crystallogr. Sect. B Struct. Sci. 2005, 61, 635-655. [CrossRef] [PubMed]

14. Teixeira, S.; Rodriguez, M.A.; Pena, P.; De Aza, A.H.; De Aza, S.; Ferraz, M.P.; Monteiro, F.J. Physical characterization of hydroxyapatite porous scaffolds for tissue engineering. Mater. Sci. Eng. 2009, C29, 1510-1514. [CrossRef]

15. Wei, G.; Ma, P.X. Structure and properties of nano-hydroxyapatite/polymer composite scaffolds for bone tissue engineering. Biomaterials 2004, 25, 4749-4757. [CrossRef] [PubMed]

16. Hoover, S.; Tarafder, S.; Bandyopadhyay, A.; Bose, S. Silver doped resorbable tricalcium phosphate scaffolds for bone graft applications. Mater Sci Eng C Mater Biol Appl. 2017, C79, 763-769. [CrossRef] [PubMed]

17. Weinstein, S.I.; Yelin, E.H.; Watkins-Castillo, S.I. The Big Picture, Burden of Musculoskeletal Diseases (BMUS). Available online: http://www.boneandjointburden.org/2014-report/i0/big-picture (accessed on 5 December 2018).

18. Uckay, I.; Pittet, D.; Vaudaux, P.; Sax, H.; Lew, D.; Waldvogel, F. Foreign body infections due to Staphylococcus epidermidis. Ann. Med. 2009, 41, 109-119. [CrossRef] [PubMed]

19. Porter, J.R.; Ruckh, T.T.; Popat, K.C. Bone tissue engineering: a review in bone biomimetics and drug delivery strategies. Biotechnol. Prog. 2009, 25, 1539-1560. [CrossRef] [PubMed]

20. Jenkins, P.J.; Phillips, S.A.; Gaston, P.; Dave, J.; Breusch, S.J. Be vigilant for secondary periprosthetic joint infection. Practitioner 2010, 254, 28-33.

21. Desai, V.G. Bharatiya Rasashastra (The Ancient Chemistry of India); Gajaanan Book Depot: Mumbai, India, 1928.

22. Santo, C.E.; Lam, E.W.; Elowsky, C.G.; Quaranta, D.; Domaille, D.W.; Chang, C.J.; Grass, G. Bacterial killing by dry metallic copper surfaces. Appl. Environ. Microbiol. 2011, 77, 794-802. [CrossRef] 
23. Grass, G.; Rensing, C.; Solioz, M. Metallic copper as an antimicrobial surface. Appl. Environ. Microbiol. 2011, 77, 1541-1547. [CrossRef] [PubMed]

24. Shanmugam, S.; Gopal, B. Copper substituted hydroxyapatite and fluorapatite: Synthesis, characterization and antimicrobial properties. Ceram. Int. 2014, 40, 15655-15662. [CrossRef]

25. Zykin, M.A.; Vasiliev, A.V.; Trusov, L.A.; Dinnebier, R.E.; Jansen, M.; Kazin, P.E. Solid state solubility of copper oxides in hydroxyapatite. J. Solid State Chem. 2018, 262, 38-43. [CrossRef]

26. Mobasherpour, I.; Heshajin, M.S.; Kazemzadeh., A.; Zakeri, M. Synthesis of nanocrystalline hydroxyapatite by using precipitation method. J. Alloys Compd. 2007, 430, 330-333. [CrossRef]

27. Gomes, S.; Vichery, C.; Descamps, S.; Martinez, H.; Kaur, A.; Jacobs, A.; Nedelec, J.M.; Renaudin, G. $\mathrm{Cu}$-doping of calcium phosphate bioceramics: From mechanism to the control of cytotoxicity. Acta Biomater. 2018, 65, 462-474. [CrossRef] [PubMed]

28. Coelho, A.A.; Chater, P.A.; Kern, A. Fast synthesis and refinement of the atomic pair distribution function. J. Appl. Cryst. 2015, 48, 869-875. [CrossRef]

29. Massiot, D.; Fayon, F.; Capron, M.; King, I.; Le Calvé, S.; Alonso, B.; Durand, J.; Bujoli, B.; Gan, Z.; Hoatson, G. Modelling one- and two-dimensional solid-state NMR spectra. Magn. Reson. Chem. 2002, 40, 70-76. [CrossRef]

30. Wang, H.; Cheng, H.; Wang, F.; Wei, D.; Wang, X. An improved 3-(4, 5-dimethylthiazol-2-yl)-2, 5-diphenyl tetrazolium bromide (MTT) reduction assay for evaluating the viability of Escherichia coli cells. J. Microbiol. Methods 2010, 82, 330-333. [CrossRef]

31. Liu, G.; Talley, J.W.; Na, C.; Larson, S.L.; Wolfe, L.G. Copper doping improves hydroxyapatite sorption for arsenate in simulated groundwaters. Environ. Sci. Technol. 2010, 44, 1366-1372. [CrossRef]

32. Bailliez, S.; Nzihou, A.; Beche, E.; Flamant, G. Removal of lead (Pb) by hydroxyapatite sorbent. Process Saf. Environ. Prot. 2004, 82, 175-180. [CrossRef]

33. Stanić, V.; Dimitrijević, S.; Antić-Stanković, J.; Mitrić, M.; Jokić, B.; Plećaš, I.B.; Raičević, S. Synthesis, characterization and antimicrobial activity of copper and zinc-doped hydroxyapatite nanopowders. Appl. Surf. Sci. 2010, 256, 6083-6089. [CrossRef]

34. Wang, C.K.; Lin, J.H.C.; Ju, C.P.; Ong, H.C.; Chang, R.P.H. Structural characterization of pulsed laser-deposited hydroxyapatite film on titanium substrate. Biomaterials 1997, 18, 1331-1338. [CrossRef]

35. Kazin, P.E.; Zykin, M.A.; Zubavichus, Y.V.; Magdysyuk, O.V.; Dinnebier, R.E.; Jansen, M. Identification of the chromophore in the apatite pigment $\left[\mathrm{Sr}_{10}\left(\mathrm{PO}_{4}\right)_{6}\left(\mathrm{Cu}_{\mathrm{x}} \mathrm{OH}_{1-\mathrm{x}-\mathrm{y}}\right)_{2}\right]$ : linear $\mathrm{OCuO}^{-}$featuring a resonance Raman effect, an extreme magnetic anisotropy, and slow spin relaxation. Chem. Eur. J. 2014, 20, 165-178. [CrossRef] [PubMed]

36. De Aza, P.N.; Guitian, F.; Santos, C.; De Aza, S.; Cusco, R.; Artus, L. Vibrational properties of calcium phosphate compounds. 2. Comparison between hydroxyapatite and $\beta$-tricalcium phosphate. Chem. Mater. 1997, 9, 916-922. [CrossRef]

37. Griffith, W.P. Raman spectroscopy of minerals. Nature 1969, 224, 264-266. [CrossRef]

38. Rothwell, W.P.; Waugh, J.S.; Yesinowski, J.P. High-resolution variable-temperature phosphorus-31 NMR of solid calcium phosphates. J. Am. Chem. Soc. 1980, 102, 2637-2643. [CrossRef]

39. Hartmann, P.; Jäger, C.; Vogel, J.; Meyer, K. Solid state NMR, X-Ray diffraction, and infrared characterization of local structure in heat-treated oxyhydroxyapatite microcrystals: an analog of the thermal decomposition of hydroxyapatite during plasma-spray procedure. J. Solid State Chem. 2001, 160, 460-468. [CrossRef]

40. Duncan, J.; MacDonald, J.F.; Hanna, J.V.; Shirosaki, Y.; Hayakawa, S.; Osaka, A.; Skakle, J.M.; Gibson, I.R. The role of the chemical composition of monetite on the synthesis and properties of $\alpha$-tricalcium phosphate. Mater. Sci. Eng. 2014, C34, 123-129. [CrossRef]

41. Duncan, J.; Hayakawa, S.; Osaka, A.; MacDonald, J.F.; Hanna, J.V.; Skakle, J.M.; Gibson, I.R. Furthering the understanding of silicate-substitution in $\alpha$-tricalcium phosphate: An X-ray diffraction, $\mathrm{X}$-ray fluorescence and solid-state nuclear magnetic resonance study. Acta Biomater. 2014, 10, 1443-1450. [CrossRef]

42. Mellier, C.; Fayon, F.; Schnitzler, V.; Deniard, P.; Allix, M.; Quillard, S.; Massiot, D.; Bouler, J.M.; Bujoli, B.; Janvier, P. Characterization and properties of novel gallium-doped calcium phosphate ceramics. Inorg. Chem. 2011, 50, 8252-8260. [CrossRef]

43. Mellier, C.; Fayon, F.; Boukhechba, F.; Verron, E.; LeFerrec, M.; Montavon, G.; Lesoeur, J.; Schnitzler, V.; Massiot, D.; Janvier, P.; et al. Design and properties of novel gallium-doped injectable apatitic cements. Acta Biomater. 2015, 24, 322-332. [CrossRef] 
44. Mathews, S.; Hans, M.; Mücklich, F.; Solioz, M. Contact killing of bacteria on copper is suppressed if bacterial-metal contact is prevented and is induced on iron by copper ions. Appl. Environ. Microbiol. 2013, 79, 2605-2611. [CrossRef] [PubMed]

45. Macomber, L.; Imlay, J.A. The iron-sulfur clusters of dehydratases are primary intracellular targets of copper toxicity. Proc. Natl. Acad. Sci. 2009, 106, 8344-8349. [CrossRef] [PubMed]

46. Kim, T.N.; Feng, Q.L.; Kim, J.O.; Wu, J.; Wang, H.; Chen, G.C.; Cui, F.Z. Antimicrobial effects of metal ions $\left(\mathrm{Ag}^{+}, \mathrm{Cu}^{2+}, \mathrm{Zn}^{2+}\right)$ in hydroxyapatite. J. Mater. Sci. Mater. Med. 1998, 9, 129-134. [CrossRef] [PubMed]

(C) 2019 by the authors. Licensee MDPI, Basel, Switzerland. This article is an open access article distributed under the terms and conditions of the Creative Commons Attribution (CC BY) license (http://creativecommons.org/licenses/by/4.0/). 